\title{
Primary Energy Consumption, CO2 Emissions and Economic Growth: Evidence from India
}

Aviral Kumar Tiwari*

Abstract:

This study examined static and dynamic causal relationships between primary energy consumption, gross domestic product, and $\mathrm{CO} 2$ emissions for India during the period 1970-2007. We tested for the presence of unit root and cointegration among the variables by incorporating endogenously determined structural breaks in the data. The causality is examined between test variables using Granger's approach (in VAR framework), and Dolado and Lütkepohl's approach. We find evidence of no cointegration relationship among the test variables in the presence of structural breaks. Further, static analysis shows that primary energy consumption does not granger-cause GDP, whereas GDP granger-causes primary energy consumption. The dynamic analysis shows conflicting results on the causal relationship between energy consumption and GDP. Since GDP explains $75.9 \%$ of the forecast error variance of primary energy consumption, whereas primary energy consumption explains only $0.96 \%$ of the forecast error variance of GDP, we can suggest that India should adopt policies that reduce energy consumption.

Keywords: CO2 emissions, primary energy consumption, economic growth, causality, IRFs, VDs, structural breaks

\section{Introduction}

The increasing threat of global warming and climate change has focused attention on the relationship between economic growth, energy consumption, and environmental pollution. A number of studies have examined the relationship between energy consumption and economic growth. This line of inquiry largely emerged from the oil shocks of the 1970's, and the impact of the Kyoto Protocol agreement. ' It should be noted that economic theories do not explicitly state a relationship among energy consumption, $\mathrm{CO}_{2}$ emissions, and economic growth. An empirical investigation on the

\footnotetext{
${ }^{1}$ The Kyoto Protocol requires that industrialized countries reduce their collective emissions of greenhouse gasses by $5.2 \%$ of 1990 levels by the period 2008-2012. The country-specific targets in the Kyoto Protocol may be difficult for some nations to achieve. Developing countries, including India, have been absolved of any responsibility towards reducing emissions in the first commitment period, that is, 2008-12, of the Kyoto Protocol.
}

relationship among these variables had been one of the most attractive areas of energy economics literature for the last two decades. Recent years have seen a renewed interest in examining the relationship between these variables. This line of research focuses on the Environmental Kuznets Curve (EKC) or what is also termed the Carbon Kuznets Curve (CKC) hypothesis. The higher economic growth rates pursued by developing countries is largely obtained through consumption of an increasing quantity of commercial energy, which comes at the cost of ignoring technologies that are more efficient. Thus,

\footnotetext{
* Aviral Kumar Tiwari

Faculty of Applied Economics,

Faculty of Management, ICFAI University Tripura

E-mail: aviral.eco@gmail.com, aviral.kr.tiwari@gmail.com
} 


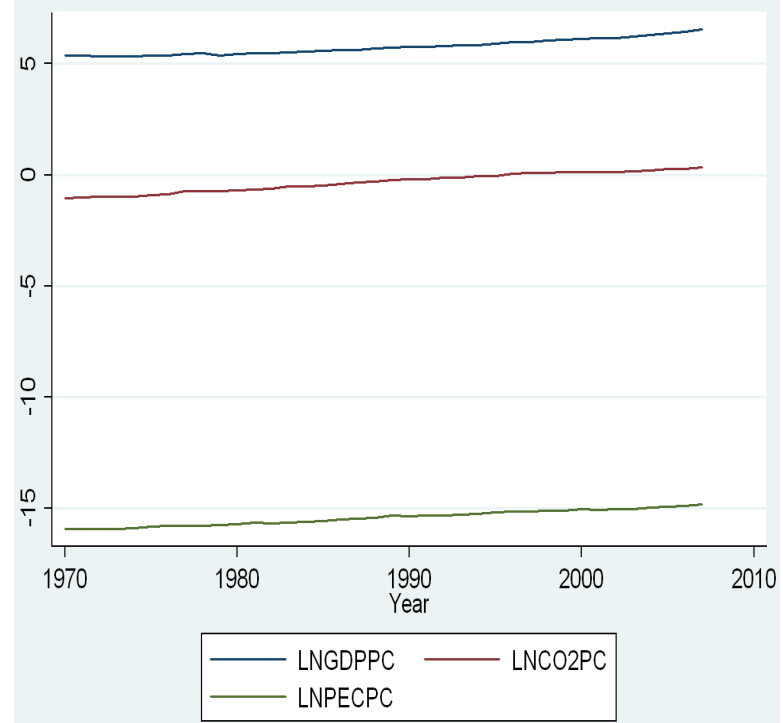

Figure 1: Plots of the variables tested in the study

there is dispute whether energy consumption is a stimulating factor, or is itself a result of economic growth. The increased share of $\mathrm{CO}_{2}$ emissions in the atmosphere that is a product of the unbridled use of fossil fuels has negative impacts on natural systems. It is a main factor contributing to climate change. In this context, the consumption of coal and oil should be replaced with renewable alternatives, such as wind, solar and hydropower, which do not emit $\mathrm{CO}_{2}$. The present study will focus on the causal relationship between economic growth (measured by gross domestic product per capita at constant prices of 2000 US\$), environmental degradation (measured by carbon dioxide $\left(\mathrm{CO}_{2}\right)$ emissions per capita) and primary energy consumption (measured by aggregate primary energy consumption per capita in Million tons oil equivalent) in India.

Figure 1 presents the trend path of the variables tested in log level and log first difference form. It is evident from the figure that primary energy consumption and economic growth have a close relationship over the entire period, thus providing reason to test the causal hypothesis in the Indian case.

The organization of the study is as follows. The second section presents a literature review followed by discussion of the objectives, data used, and econometric methodology in the third section. The fourth section discusses the data analysis and the empirical results. The fifth section concludes the study and provides policy implications.

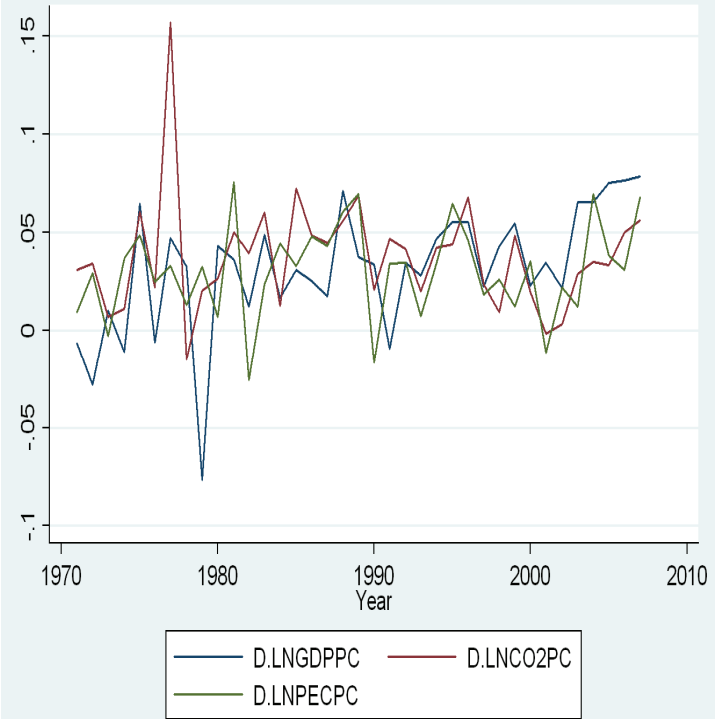

\section{Literature Review}

The studies in this area can be classified into four groups based on their findings. The first group comprises studies that find unidirectional causality running from electricity or energy consumption (both at aggregate and disaggregate levels) to GDP. Studies worthy of mention are those by Altinay and Karagol (2005) in Turkey for the period 1950-2000, Lee and Chang (2005) in Taiwan for the period 1954-2003, Shiu and Lam (2004) in China for the period 1971-2000, and Soytas and Sari (2003) in Turkey, France, Germany and Japan, Wolde-Rufale (2004) in Shanghai for the period 1952-1999, and Morimoto and Hope (2004) in Sri-Lanka for the period 1960-98.

Second are those studies that find a unidirectional causality running from economic growth or gross domestic product to electricity or energy consumption. Noteworthy studies are Ghosh (2002) for India during 1950-1997, Cheng (1999) in India for the period 19521995, Fatai et al. (2004) in New Zealand and Australia for the period 1960-1999, Hatemi and Irandoust (2005) in Sweden for the period 1965-2000, Cheng and Lai (1997) in Taiwan for the period 1954-1993, Chang and Wong (2001) in Singapore for the period 1975-1995, and Aqeel and Butt (2001) in Pakistan for the period 1955-1996.

Third are those studies that find bidirectional causality. Studies worth noting are Soytas and Sari (2003) in Argentina, Oh and Lee (2004) in Korea for the period 1970-1999, Yoo (2005) in Korea for the period 1970-2002, Glasure (2002) in South Korea for the period 1961-1990, Jumbe (2004) in Malawi for the period 1970-1999, Ghali and El-Sakka (2004) in Canada for the period of 1961- 
1997, and Hwang and Gum (1992) in Taiwan for the period 1961-1990.

The fourth group comprises studies that that find no causal linkages between energy or electricity consumption and economic growth. These are Cheng (1995) in the U.S. for the period 1947-1990, Stern (1993) in the U.S. for the period 1947-1990, Akarca and Long (1980) in the U.S. for the period 1950-1968 and 1950-1970, Yu and Hwang (1984) in the U.S. for the period 1947-1979. A comprehensive review of the literature on this topic is provided in many studies, for example Shahbaz, Tang, Shabbir (2011) and Tiwari (2011a, 2011b) and the references therein, among others.

A marriage of these two literatures that brings together the relationship between economic growth, energy consumption and pollution emissions within a Granger-causality multivariate framework is a relatively new area of research. There exist only a limited number of studies in this direction either for developed countries (for example, Ang (2007) for France, Soytas, Sari and Ewing (2007) for the United States) or developing countries (for example, Zhang and Cheng (2009) for China, Ang (2008) for Malaysia, Halicioglu (2009) and Soytas and Sari (2009) for Turkey, Sari and Soytas (2009) for oil-rich OPEC countries). However, to the best of our knowledge there has been no such study conducted for India that analyzes the causality in a multivariate framework with structural breaks in the unit root and cointegration process. Tiwari (2011a, 2011b) analyzes the causality in a multivariate framework, but it fails to incorporate structural breaks in the unit root and cointegration process. Further, use of primary energy consumption is also new in the study as Tiwari (2011a, 2011b) and other studies used electricity consumption as a proxy for energy consumption.

\section{Data, Objectives, and Econometric Methodology}

\subsection{Data and objectives}

The present study has taken annual time series data for the period 1970-2007 from the World Development Indicators (WDI) and BP Statistical Review of World Energy ${ }^{2}$.
The present study analyzes the static and dynamic relationship among primary energy consumption, $\mathrm{CO}_{2}$ emissions, and economic growth by incorporating structural breaks in the unit root and cointegration process of these variables. The interest in studying the relationship between primary energy consumption, $\mathrm{CO}_{2}$ emissions, and economic growth arises from the need to understand the complex links between the three variables. Such an understanding is basic to regulators and investors in deregulated electricity markets in order to design a system that ensures reliability and efficiency.

\subsection{Estimation methodology}

The stationarity of the variables is tested by using the (Augmented) Dickey Fuller (1979, hereafter DF/ADF) test, Phillips and Perron (1988, hereafter PP) test and Ng and Perron (2001, hereafter NP) test, and in all cases model selection was based on the graphical plot of the variables in question.

However, these tests can yield misleading results when the data series exhibits socks. Therefore, we used the Zivot and Andrews (1992, hereafter ZA) test in our analysis, as it treats the selection of the break points as the outcome of an estimation procedure. The ZA (1992) test tests the null hypothesis of the unit root against the alternative of a one-time structural break with three models: Model A allows a one-time change in the level of the series, Model $B$ permits a one-time change in the slope of the trend function of the series and Model $C$ admits both changes. The regression equations corresponding to these three models are as following.

Model A:

$$
\Delta y=\mu+\beta t+\alpha y_{t-1}+\theta D U_{t}+\sum_{i=1}^{k} c_{i} \Delta y_{t-i}+\varepsilon_{t}
$$

Model B:

$$
\Delta y=\mu+\beta t+\alpha y_{t-1}+\gamma D T_{t}+\sum_{i=1}^{k} c_{i} \Delta y_{t-i}+\varepsilon_{t}
$$

Model C:

$$
\Delta y=\mu+\beta t+\alpha y_{t-1}+\theta D U_{t}+\gamma D T_{t}+\sum_{i=1}^{k} c_{i} \Delta y_{t-i}+\varepsilon_{t}
$$

\footnotetext{
${ }^{2}$ http://databank.worldbank.org/ddp/home.do?Step $=12 \&$ id $=4 \& C N O=2$ and http://www.bp.com/statisticalreview.
} 
where DUt and DTt are break dummy variables for a mean shift and a trend shift, respectively. The shift occurs at each possible break point $T_{B}\left(1<T_{B}<T\right)$. Formally:

$$
\begin{aligned}
& D U_{t}=\left\{\begin{array}{l}
1, \text { if }, t>T_{B} \\
0, \text { otherwise }
\end{array}\right. \text { and } \\
& D T_{t}=\left\{\begin{array}{l}
t-T_{B}, \text { if }, t>T_{B} \\
0, \text { otherwise }
\end{array}\right.
\end{aligned}
$$

where $k$ is the number of lags determined for each possible break point by one of the information criteria (AIC in the study). The null hypothesis is $\alpha=0$, which implies that the series exhibits a unit root with a drift and excludes any structural break points. The alternative hypothesis is $\alpha<0$, which implies that the series is trend-stationary with an unknown one-time break. Therefore, equations (1), (2) and (3) are sequentially estimated and $T_{B}$ is chosen so as to minimize the one sided t-statistics for testing $\hat{\alpha}=0$.

However, the ZA (1992) test incorporates only one structural break in the data even if more than one break is present. To overcome this issue, the Clemente-MontanesReyes (1998) unit root test was applied. This test has the following representation of the null hypothesis i.e., $H_{0}$ and alternative hypothesis i.e., $H_{a}$ :

$$
\begin{aligned}
& H_{0}: x_{t}=x_{t-1}+a_{1} D_{T B}+a_{2} D_{1 t}+\mu_{t} \\
& H_{a}: x_{t}=u+b_{1} D U_{1 t}+b_{2} D T B_{2 t}+\mu_{t}
\end{aligned}
$$

In equation-4 and equation-5, DTB $B_{1 t}$ is the pulse variable equivalent to 1 if $t=T B_{i}+1$ and zero if not. Moreover, $D U_{i t}=1$ if $T B_{i}<t(i=1,2)$ and if this assumption is violated then it is equal to zero. The modification of the mean is represented by the $T B_{1}$ and $T B_{2}$ time periods. Further, it is simplified with the assumption that $T B_{i}=\delta_{i} T(i=1,2)$ where $1>\delta_{i}>0$ while $\delta_{1}<\delta_{2}$ (see Clemente-Montanes-Reyes (1998)). If an innovative outlier contains two structural breaks then we can test the unit root hypothesis with the following equation-6:

$x_{t}=u+\rho x_{t-1}+d_{1} D T B_{1 t}+a_{2} D T B_{2 t}+d_{3} D U_{1 t}+d_{4} D U_{2 t}+\sum_{i=1}^{k} c_{j} \Delta x_{t-1}+\mu_{t}$

This equation helps us to estimate the minimum value of the t-ratio through simulations and the value of the simulated t-ratio can be utilized for all break points if the value of the autoregressive parameter is constrained to 1 . For the derivation of the asymptotic distribution of the said estimate, it is supposed that $\delta_{2}>\delta_{1}>0$, $1>\delta_{2}-1>\delta_{0} . \delta_{1}$ and $\delta_{2}$ obtain the values in the interval i.e. $[(t+2) / T,(T-1) / T]$ by appointing the largest window size. Further, $\delta_{1}<\delta_{2}+1$ was used to show that cases where break points exist in repeated periods are purged (see Clemente-Montanes-Reyes (1998)). To test the unit root hypothesis, a two-step approach was used for the case when shifts are in a better position to explain additive outliers. In the $1^{\text {st }}$ step, the deterministic variable was eliminated from the estimation with the use of the following equation-7:

$$
x_{t}=u+d_{5} D U_{1 t}+d_{6} D U_{2 t}+\hat{x}
$$

Then, in the second step, the minimum t-ratio was searched and hypothesis $\rho=1$ was tested with equation 8:

$\widehat{x}_{t}=\sum_{i=1}^{k} \phi_{1 i} D T B_{1 t-1}+\sum_{i=1}^{k} \phi_{2 i} D T B_{2 t-1}+\rho \widehat{x}_{t-1}+\sum_{i=1}^{k} c_{i} \Delta \widehat{x}_{t-1}+\mu_{t}$

To make sure that $\min t_{\rho_{t}}^{I O}\left(\delta_{1}, \delta_{2}\right)$ congregates, i.e., converges with the distribution, a dummy variable was included in the estimated equation for estimation:

$$
\min t_{\rho_{t}}^{I O}\left(\delta_{1}, \delta_{2}\right) \rightarrow \inf _{\gamma}=\wedge \frac{H}{\left[\delta_{1}\left(\delta_{2}-\delta_{1}\right)\right]^{1 / 2} K^{1 / 2}}
$$

After confirming that the variables used in this study are non-stationary and have the same order of integration i.e., I(1), the Johansen and Juselius (1990) method of cointegration analysis was adopted. The method employs the VAR system to test for the numbers of cointegration vectors. Its estimation procedure is based on the Maximum Likelihood (ML) method. However, in this case, if structural breaks are not also analyzed it may lead to biased results. There are a number of studies that address testing for cointegration in the presence of structural shifts (for example Hansen (1992), Gregory and Hansen (1996), Campos, Ericsson, and Hendry (1996), Seo (1998), Inoue (1999), Johansen and Nielsen (1993), Johansen, Mosconi, and Nielsen (2000), Arranz and Escribano (2000), Saikkonen and Lütkepohl (2000, hereafter S\&L), and Lütkepohl, Saikkonen, and Trenkler (2003)). These studies considered a single equation as well as systems cointegration tests, but none of the proposed tests is suitable for testing the cointegrating rank of a system when the break date is 
unknown. For such a situation Lütkepohl, Saikkonen, and Trenkler (2004) proposed a cointegrating rank test for vector autoregressive (VAR) processes with a structural shift at an unknown time. In their case, the shift is assumed as a simple shift in the mean. They modeled a structural shift as a simple shift in the level of the process. The structural break date is estimated based on a fullunrestricted VAR model. In the next step, the Johansen type test was applied for the cointegrating rank to the adjusted series using the following null and alternative hypotheses:

$$
H_{0}\left(r_{0}\right): r k(\Pi)=r_{0} \text { vs. } H_{1}\left(r_{0}\right): r k(\Pi)>r_{0}
$$

For a given break date, S\&L propose to estimate the parameters of the deterministic part first. Denoting the estimators of $\mu_{0}, \mu_{1}$, and $\delta$ by $\hat{\mu}_{0}, \hat{\mu}_{1}$, and $\hat{\delta}$, respectively, the test is based on a sample analog of the series $\mathrm{x}_{\mathrm{t}}$ obtained as

$\hat{x}_{t}=y_{t}-\hat{\mu}_{0}-\hat{\mu}_{1} t-\hat{\delta} d_{t \hat{\tau}}$,

where $\hat{\tau}$ may be replaced by any estimator that satisfies $\hat{\tau}=\tau+O p(1)$ including, of course, $\hat{\tau}$. The series $\hat{x}_{t}$ can be used to compute LR type test statistics for the null hypothesis $H_{0}\left(r_{0}\right)$ in the same way as the usual LR test statistic based on the VECM. More precisely, the test statistic can be determined from

$$
\Delta \hat{x}_{(t)}=\Pi \hat{x}_{t-1}+\sum_{j=1}^{p-1} \Gamma_{j} \Delta \hat{x}_{(t-j)}+e_{t \hat{\tau}}
$$$$
(t=p+1, \ldots, T),
$$

by solving the generalized eigenvalue problem det( $\left.\hat{\Pi} \hat{M}_{T} \Pi{ }^{\prime}-\lambda \hat{\Omega}\right)=0$, where $\hat{\Pi}$ is the LS estimator of $\Pi$ obtained from (12), $\hat{\Omega}$ is the corresponding residual covariance matrix, and

$$
\begin{aligned}
\hat{M}_{(t)} & =\sum_{t=p+1}^{T} \hat{x}_{(t-j)} \hat{x}_{(t-j)}^{\prime} \\
& -\sum_{t=p+1}^{T} \hat{x}_{(t-j)} \Delta \hat{X}_{(t-j)}^{\prime}\left(\sum_{t=p+1}^{T} \Delta \hat{X}_{(t-j)} \Delta \hat{X}_{(t-j)}^{\prime}\right)^{-1} \sum_{t=p+1}^{T} \Delta \hat{X}_{(t-j)} \Delta \hat{x}_{(t-j)}^{\prime}
\end{aligned}
$$

with $\Delta \hat{X}_{(t-j)}=\left[\Delta \hat{x}_{(t-1)}^{\prime}: \ldots: \Delta \hat{x}_{(t-p+1)}^{\prime}\right]^{\prime}$. Denoting the resulting ordered eigenvalues by $\hat{\lambda}_{1} \geq \ldots \geq \hat{\lambda}_{n}$, the $\mathrm{LR}$ type statistic for the pair of hypotheses in (10) becomes

$$
L R\left(r_{0}\right)=\sum_{j=r_{0}+1}^{n} \log \left(1+\hat{\lambda}_{j}\right)
$$

Once the cointegrating vectors are estimated among a set of variables one can proceed to carry out VEC modeling. However, Lütkepohl, Saikkonen, and Trenkler's (2004) test of cointegration in the presence of an endogenously determined structural break shows no evidence of cointegration (panel two of Table 3). Therefore, to analyze the static and dynamic causality framework the VAR approach was used, and to see the robustness of the results of the VAR model Toda and Yamamoto's (1995, hereafter TY) and Dolado and Lütkepohl's (1996, hereafter DL) test was applied. The test involves estimating the VAR in levels and testing general restrictions on the parameter matrices. This method is applicable "whether the variables may be stationary (around a deterministic trend), integrated in an arbitrary order, or cointegrated in an arbitrary order". Therefore, the Toda and Yamamoto (1995) causality procedure has been labeled as the long run causality test of the coefficients of VAR. The TY and DL procedure steps are as follows: (i) finding the maximal order of integration $(d)$ of variables by conducting unit root tests, (ii) determining the optimum lag length ( $k$ ) of a VAR. (iii) estimating the lag-augmented VAR $(k+d)$ model, (iv) conducting a Wald test on the first $k$ parameters instead of on all parameters in the augment VAR $(k+d)$ model.

To employ the DL test, first the lag length of an unrestricted multivariate VAR model was estimated and optimal lag length 3 by means of the AIC because of its small sample properties (Liew, 2004) was chosen. Then the following equation was estimated through the Seemingly Unrelated Regression (SUR) approach: 


$$
\begin{aligned}
{\left[\begin{array}{l}
l y_{(t)} \\
l e_{(t)} \\
l C O_{2(t)}
\end{array}\right]=} & {\left[\begin{array}{l}
a_{01} \\
a_{02} \\
a_{03}
\end{array}\right]+\left[\begin{array}{ll}
a_{11}^{1} & a_{12}^{1} \\
a_{21}^{1} & a_{22}^{1} \\
a_{31}^{1} & a_{23}^{1} \\
a_{32} & a_{33}^{1}
\end{array}\right]\left[\begin{array}{l}
l y_{(t-1)} \\
l e_{(t-1)} \\
l C O_{2(t-1)}
\end{array}\right] } \\
& +\left[\begin{array}{l}
a_{11}^{2} a_{12}^{2} a_{13}^{2} \\
a_{21}^{2} a_{22}^{2} a_{23}^{2} \\
a_{31}^{2} a_{32}^{2} a_{33}^{2}
\end{array}\right]\left[\begin{array}{l}
l y_{(t-2)} \\
l e_{(t-2)} \\
l C O_{2(t-2)}
\end{array}\right] \\
& +\left[\begin{array}{l}
a_{11}^{3} a_{12}^{3} a_{13}^{3} \\
a_{21}^{3} a_{22}^{3} a_{23}^{3} \\
a_{31}^{3} a_{32}^{3} a_{33}^{3}
\end{array}\right]\left[\begin{array}{l}
l y_{(t-3)} \\
l e_{(t-3)} \\
l C O_{2(t-3)}
\end{array}\right] \\
& +\left[\begin{array}{l}
a_{11}^{4} a_{12}^{4} a_{13}^{4} \\
a_{21}^{4} a_{22}^{4} a_{23}^{4} \\
a_{31}^{4} a_{32}^{4} a_{33}^{4}
\end{array}\right]\left[\begin{array}{l}
l y_{(t-4)} \\
l e_{(t-4)} \\
l C O_{2(t-4)}
\end{array}\right]+\left[\begin{array}{l}
\varepsilon_{1 t} \\
\varepsilon_{2 t} \\
\varepsilon_{3 t}
\end{array}\right]
\end{aligned}
$$

where $l y_{(t)}, l e_{(t)}$ and $l C O_{2(t)}$ denote the logarithms of the real GDP, primary energy consumption, and $\mathrm{CO}_{2}$ emissions, respectively. To test the causality among the test variable the hypothesis can be constructed that energy consumption does not cause real GDP: $H_{0}: a_{12}^{(1)}=a_{12}^{(2)}=a_{12}^{(3)}=0$ and that real GDP does not cause energy consumption, constructed as: $H_{0}: a_{21}^{(1)}=a_{21}^{(2)}=a_{21}^{(3)}=0$ while these joint hypotheses can be tested by the MWALD test.

Further, diagnostic checks are conducted to test the stochastic properties of the VAR model. We tested for the presence of residuals autocorrelation (this is tested by using the Lagrange Multiplier (LM) test), heteroskedasticity (tested by using the White heteroskedasticity test), normality (tested by the JarqueBera (JB) normality test and adopting Urzua's (1997) method of residual factorization (orthogonalization)) and the presence of lag exclusion (tested by conducting the Wald type lag exclusion test). ${ }^{3}$

The F-test in VAR only indicates the Grangerexogenity or endogenity of the dependent variable within the period under consideration (i.e., it only indicates the static causality). In order to analyze the dynamic causality of the system the forecast error Variance Decompositions (VDs) and Impulse Response

${ }^{3}$ For more details on why these tests have been preferred see Tiwari (2011a, 2011b).
Functions (IRFs) were computed using a generalized approach, while confidence intervals were constructed with 10000 Monte Carlo repetitions.

\section{Data Analysis and Result Interpretations}

\subsection{Descriptive analysis}

Summary statistics of the variables are presented in Table 1.

It is evident from Table 1 that the $\mathrm{SD}$ of $\mathrm{CO}_{2}$ emissions is highest and the GDP lowest, while very close to the SD value of primary energy consumption. The mean value of $\mathrm{CO}_{2}$ emissions and primary energy consumption are negative while GDP is positive. JB statistics shows that all of the variables used in the analysis have a log normal distribution.

\subsection{Unit root, cointegration, granger-causality analysis in a static frame work (using VAR and Dolado and Lütkepohl's approach) and dynamic framework (using IRF $F_{s}$ and $\left.V D_{S}\right)$}

The stationary property of the data series was tested with the use of DF/ADF test, PP test, and NP test based upon the Figure 1 suggest the type of the model to be used. The results of the unit roots are reported in Table 2 .

It is evident from Table 2 that all of the variables are nonstationary in their level form and become stationary after the first difference i.e., (I). Further, to see the robustness of the results of the traditional unit root ZA test of one structural break and the CMR test of one break in the case of Innovative Outliers and Additive Outliers was performed and the results are reported in Table 3 .

The results of models $A, B$, and $C$ of the $Z A$ test show that GDP per capita is nonstationary in the level form and structural breaks occurred in the series in 1979, 2002 and 2003. These years in Indian history are characterized as policy shock years. Similarly, primary energy consumption per capita is also nonstationary in the level form and structural breaks in the series occurred in 1987 and 1996. In the case of per capita $\mathrm{CO}_{2}$ emissions, structural breaks have occurred in 1995, 1997 and 2001 and it is stationary in the level form. The results of the CMR test of one break show different dates for structural breaks than ZA, which is due to the difference in the underlying procedures of testing the break points. However, both results provide the same conclusion that test variables are nonstationary in the level form, whereas they are stationary in the first 
Primary Energy Consumption, CO2 Emissions and Economic Growth: Evidence from India

\begin{tabular}{|l|c|c|c|}
\hline & $\operatorname{Ln}(\mathrm{GDPPC})$ & $\operatorname{Ln}(\mathrm{PECPC})$ & $\operatorname{Ln}\left(\mathrm{CO}_{2} \mathrm{PC}\right)$ \\
\hline Mean & 5.759298 & -15.42188 & -0.316019 \\
\hline Median & 5.711097 & -15.38977 & -0.262979 \\
\hline Maximum & 6.532876 & -14.82226 & 0.359288 \\
\hline Minimum & 5.330333 & -15.94910 & -1.032574 \\
\hline Std. Dev. & 0.355009 & 0.343749 & 0.436976 \\
\hline Skewness & 0.546480 & 0.016641 & -0.164199 \\
\hline Kurtosis & 2.134151 & 1.688451 & 1.671210 \\
\hline $\begin{array}{l}\text { Jarque-Bera } \\
\text { Probability) }\end{array}$ & $\begin{array}{l}\text { 3.078406 } \\
(0.214552)\end{array}$ & 2.725342 & 2.966421 \\
\end{tabular}

Note: $\operatorname{Ln}(G D P P C)$ denotes log of Gross domestic product per capita; $\operatorname{Ln}(\mathrm{PECPC})$ denotes log of electricity consumption per capita; $\mathrm{Ln}\left(\mathrm{CO}{ }_{2} \mathrm{PC}\right)$ denotes $\log$ of $\mathrm{CO}_{2}$ emissions per capita.

Source: Author's calculation

Table1: Descriptive statistical analysis

\begin{tabular}{|c|c|c|c|c|c|c|}
\hline \multirow[t]{3}{*}{ Variables } & \multicolumn{6}{|c|}{ Unit root tests } \\
\hline & \multirow[t]{2}{*}{ Constant } & \multirow{2}{*}{$\begin{array}{l}\text { Constant } \\
\text { and trend }\end{array}$} & \multirow[t]{2}{*}{ DF/ADF (K) } & \multirow[t]{2}{*}{$\mathrm{PP}(\mathrm{k})$} & \multicolumn{2}{|l|}{ NP } \\
\hline & & & & & $(\mathrm{MZa})(\mathrm{k})$ & $(\mathrm{MZt})(\mathrm{k})$ \\
\hline $\operatorname{Ln}(G D P P C)$ & ------ & Yes & $-0.81194(0)$ & $-0.68639(1)$ & $0.05191(0)$ & $0.02117(0)$ \\
\hline $\mathrm{D}(\operatorname{Ln}(G D P P C))$ & Yes & ---- & $-4.8774^{*}(0)$ & $-4.9307^{*}(3)$ & $-16.483^{*}(0)$ & $-2.7427^{*}(0)$ \\
\hline $\operatorname{Ln}(P E C)$ & $\begin{array}{ll}--- \\
\end{array}$ & Yes & $-2.89389(0)$ & $-2.93676(2)$ & $-9.91251(0)$ & $-2.16379(0)$ \\
\hline $\mathrm{D}(\operatorname{Ln}(\mathrm{PEC}))$ & Yes & ------ & $-6.7924 *(0)$ & $-6.7924^{*}(0)$ & $-17.4514^{*}(0)$ & $-2.82526^{*}(0)$ \\
\hline $\operatorname{Ln}\left(\mathrm{CO}_{2} \mathrm{PC}\right)$ & ---- & Yes & $-1.7721(0)$ & $-1.6853(1)$ & $-6.29739(0)$ & $-1.72346(0)$ \\
\hline $\mathrm{D}\left(\mathrm{Ln}\left(\mathrm{CO}_{2} \mathrm{PC}\right)\right)$ & Yes & ----- & $-7.1026^{*}(0)$ & $-7.0827^{*}(2)$ & $-17.2730 *(0)$ & $-2.91941^{*}(0)$ \\
\hline
\end{tabular}

Note: (1) Ln(GDPPC) denotes log of Gross domestic product per capita; Ln(PECPC) denotes log of electricity consumption per capita; $\mathrm{Ln}\left(\mathrm{CO}_{2} \mathrm{PC}\right)$ denotes log of $\mathrm{CO}_{2}$ emissions per capita. (2) *denotes significance at $1 \%$ level. (3) "K" Denotes lag length and "D" denotes first difference. (4) Selection of lag length in NP test is based on Spectral GLS-detrended AR based on SIC and selection of lag length (Bandwidth) and in PP test it is based on Newey-West using Bartlett kernel.

Source: Author's calculation

Table 2: Unit root analysis

\begin{tabular}{|c|c|c|c|c|c|c|c|c|c|c|}
\hline \multicolumn{5}{|c|}{ Clemente-Montanes-Reyes Unit Root } & \multicolumn{6}{|c|}{ ZA unit root test } \\
\hline \multirow[t]{2}{*}{ Variables } & \multicolumn{2}{|c|}{ Innovative Outliers } & \multicolumn{2}{|c|}{ Additive Outlier } & \multicolumn{2}{|c|}{ Model A } & \multicolumn{2}{|c|}{ Model B } & \multicolumn{2}{|c|}{ Model C } \\
\hline & t-statistic & Decision & t-statistic & Decision & t-statistic & Decision & t-statistic & Decision & t-statistic & Decision \\
\hline Ln(GDPPC) & $\begin{array}{l}.761 \\
(1986)\end{array}$ & $\mathrm{I}(0)$ & $\begin{array}{l}-1.621 \\
(2000)\end{array}$ & $\mathrm{I}(0)$ & $\begin{array}{l}-2.490 \\
(1979)\end{array}$ & $\mathrm{I}(0)$ & $\begin{array}{l}-2.671 \\
(2002)\end{array}$ & $\mathrm{I}(0)$ & $\begin{array}{l}-2.677 \\
(2003)\end{array}$ & $\mathrm{I}(0)$ \\
\hline $\mathrm{D}(\operatorname{Ln}(\mathrm{GDPPC}))$ & \begin{tabular}{|l}
-6.576 \\
$(1978)$ \\
\end{tabular} & $\mathrm{I}(1)$ & $\begin{array}{l}-6.206 \\
(2000) \\
\end{array}$ & $\mathrm{I}(1)$ & $\begin{array}{l}-7.438 \\
(1991) \\
\end{array}$ & $\mathrm{I}(1)$ & $\begin{array}{l}-7.445 \\
(2003) \\
\end{array}$ & $\mathrm{I}(1)$ & $\begin{array}{l}-7.685 \\
(1979) \\
\end{array}$ & $\mathrm{I}(1)$ \\
\hline $\operatorname{Ln}(\mathrm{PECPC})$ & \begin{tabular}{|l}
-1.621 \\
$(1983)$
\end{tabular} & $\mathrm{I}(0)$ & $\begin{array}{l}-1.843 \\
(1990)\end{array}$ & $\mathrm{I}(0)$ & $\begin{array}{l}-3.869 \\
(1987)\end{array}$ & $\mathrm{I}(0)$ & $\begin{array}{l}-2.979 \\
(1996)\end{array}$ & $\mathrm{I}(0)$ & $\begin{array}{l}-3.773 \\
(1987) \\
\end{array}$ & $\mathrm{I}(0)$ \\
\hline $\mathrm{D}(\operatorname{Ln}(\mathrm{PECPC}))$ & \begin{tabular}{|l}
-7.216 \\
$(1988)$
\end{tabular} & $\mathrm{I}(1)$ & $\begin{array}{l}-7.381 \\
(1987)\end{array}$ & $\mathrm{I}(1)$ & $\begin{array}{l}-7.538 \\
(1990)\end{array}$ & $\mathrm{I}(1)$ & $\begin{array}{l}-7.057 \\
(2003)\end{array}$ & $\mathrm{I}(1)$ & $\begin{array}{l}-7.550 \\
(2001)\end{array}$ & $\mathrm{I}(1)$ \\
\hline $\operatorname{Ln}\left(\mathrm{CO}_{2} \mathrm{PC}\right)$ & \begin{tabular}{|l}
-1.267 \\
$(1983)$
\end{tabular} & $\mathrm{I}(0)$ & $\begin{array}{l}-2.044 \\
(1990)\end{array}$ & $\mathrm{I}(0)$ & $\begin{array}{l}-4.331 \\
(2001)\end{array}$ & $\mathrm{I}(0)$ & $\begin{array}{l}-4.154 \\
(1997)\end{array}$ & $\mathrm{I}(0)$ & $\begin{array}{l}-3.956 \\
(1995)\end{array}$ & $\mathrm{I}(0)$ \\
\hline $\mathrm{D}\left(\mathrm{Ln}\left(\mathrm{CO}_{2} \mathrm{PC}\right)\right)$ & $\begin{array}{l}-9.225 \\
(1976)\end{array}$ & $\mathrm{I}(1)$ & $\begin{array}{l}-5.956 \\
(1975)\end{array}$ & $\mathrm{I}(1)$ & $\begin{array}{l}-7.721 \\
(1975)\end{array}$ & $\mathrm{I}(1)$ & $\begin{array}{l}-7.567 \\
(1978)\end{array}$ & $\mathrm{I}(1)$ & $\begin{array}{l}-7.817 \\
(2001)\end{array}$ & $\mathrm{I}(1)$ \\
\hline
\end{tabular}

ZA test-Critical values: 1\%: -5.57 5\%: -5.08 for model when breaks occur in intercept and trend both; Critical values: $1 \%$ : -5.43 5\%: 4.80 for model when breaks occur in intercept only; Critical values: $1 \%$ : -4.93 5\%: -4.42 for model when breaks occur in trend only. CMR test critical values for $I O$ and $A O$ models is -4.270 and -3.560 at $5 \%$ level of significance, respectively.

\section{Table-3: ZA and Clemente-Montanes-Reyes Unit Root Estimation with one structural break}

difference from i.e., I(1). Finally, to validate the findings of one structural break the results of the two-break test of CMR in the case of Innovative Outliers and Additive Outliers was analyzed and the results are reported in Table 4.
It is evident from Table 4 that there is a difference in the identified dates of structural breaks in the cases of the Innovative Outliers' and Additive Outliers' approaches. However, each series is nonstationary in the level form and stationary in the first difference form. This indicates 
that all test variables have integration of the order of one i.e., I(1).

Since all variables are I(1) cointegration analysis can proceed. To proceed on to cointegration the first step is the selection of appropriate lag length ${ }^{4}$. Therefore, a joint test of lag length selection was carried out, and (based upon AIC) to take three lags of each variable. Then lag intervals $(1,3)$ were chosen and a joint test ${ }^{5}$ was conducted for the cointegrating vector and model selection. Further, by choosing model $4^{6}$, and the lag interval $(1,3)$ the $J J$ cointegration test was carried out. The results of the cointegration test are reported in Table 5 .

It is evident from panel 1 of Table 5 that both Trace and Eigenvalue criteria reject the null hypothesis of no cointegrating vector against the alternative of at most one cointegrating vector. Further, to test the robustness of the results of cointegration Lütkepohl, Saikkonen, and Trenkler's (2004) test of cointegration was performed and the results are reported in panel 2 of Table 5 . Interestingly, in this case no null hypothesis of cointegration is rejected. This implies that the results reported by the $\mathrm{J}$ test are unbiased and therefore we cannot conduct the VECM analysis. As a consequence the next step was the Engle-Granger causality analysis in the VAR framework using lag intervals $(1,3)$, the results of which are shown in Table 6.

It is evident from Table 6 that $\mathrm{CO}_{2}$ emissions Grangercause GDP and that $\mathrm{CO}_{2}$ emissions and primary energy consumption Granger-cause GDP jointly. Further, we find that GDP Granger-causes primary energy consumption.

\footnotetext{
${ }^{4}$ The JJ test has been found to be sensitive to the lag length chosen for the analysis. When the order of VAR i.e., lag length is too short, the problem of serial correlation among the residuals arises and the test statistic will become unreliable. Conversely, if lag length (order of VAR) is too high there will be an upward bias in the test statistics, again causing doubts on the reliability of the estimates of parameters. Therefore, we used Akaike Information Criteria (AIC) because of its small sample properties.

${ }^{5}$ The $\mathrm{JJ}$ test has also been found to be sensitive to the choice of deterministic assumptions used in testing cointegration. Johansen (1991) suggests testing the joint hypothesis of the rank order and the deterministic components to choose the right model. This test is known as the Pantula Principal. Since we were not sure whether a deterministic trend is present or whether the VAR also had a linear trend we carried out a joint test and chose the model, which minimizes the value of SIC and AIC and in the case of conflict the theoretically appropriate model was chosen which minimizes the values of SIC of VEC modeling.

${ }^{6}$ It should be noted that the joint test of model selection and cointegrating vector shows that model 5 is appropriate (based upon SIC and AIC) for analysis. However, model 1 and model 5 have been said to be theoretically inappropriate; hence we preferred the model in which we obtained the minimum values of SIC and AIC, i.e., model 4.
}

Further, to check that the conclusions drawn from the VAR model are unbiased we performed diagnostic checks analysis and report the results in Table 7.

It is evident from Table 7 that the specification of VAR is correct as no test rejects the null hypothesis (of course, the null of lag exclusion is rejected, which implies no lag is excluded from the model of any variable). Therefore, in the final step, IRFs and VDs analysis were performed and standard errors in both cases obtained by conducting 10000 Monte-Carlo simulations. A graph of the accumulated IRFs is given in Figure 2 .

It is evident from Figure 2 that one SD shock/innovation in GDP, primary energy consumption, and $\mathrm{CO}_{2}$ emissions increases GDP, primary energy consumption, and $\mathrm{CO}_{2}$ emissions throughout the 10 years. Whereas by analyzing the results of VDs it was found that GDP, primary energy consumption and $\mathrm{CO}_{2}$ emissions explains $96 \%, 0.96 \%$ and $2.8 \%$ of the forecast error variance in GDP after 10 years. Further, the results of VDs analysis show that GDP, primary energy consumption and $\mathrm{CO}_{2}$ emissions explain $75.9 \%, 20.5 \%$, and $3.63 \%$ of forecast error variance in primary energy consumption. Finally, the VDs results show that GDP, primary energy consumption and $\mathrm{CO}_{2}$ emissions explain $64.9 \%, 19.5 \%$, and $15.55 \%$ of forecast error variance in $\mathrm{CO}_{2}$ emissions. Thus, conflicting results between VDs and IRFs were shown. The IRFs analysis shows evidence of bidirectional causality, whereas VDs analysis shows evidence of unidirectional causality (this is because GDP explains most of the forecast error variance in primary energy consumption and $\mathrm{CO}_{2}$ emissions and not vice-versa).

In the final step, the DL approach of Granger-causality was applied to test the validity of the results reported by the simple VAR model, with the results presented in Table 8.

It is evident from Table 8 that the results of the DL approach support the results of the VAR based Grangercausality analysis (the only exception is that now $\mathrm{CO}_{2}$ emissions are found to Granger-cause primary energy consumption).

\section{Conclusions, policy implications and limitations}

The paper examined the linkage between primary energy consumption, $\mathrm{CO}_{2}$ emissions, and economic growth in India for the period 1970-2007. The relationship was examined within static and dynamic Granger causality frameworks. The VAR approach and DL approach were used for examining the causality in the 


\begin{tabular}{|l|l|l|l|l|l|l|l|l|}
\hline \multicolumn{1}{|c|}{ Clemente-Montanes-Reyes Unit Root } \\
\hline \multicolumn{1}{|c|}{ Variables } & \multicolumn{3}{|c|}{ Innative Outliers } & \multicolumn{5}{c|}{ Additive Outlier } \\
\hline & t-statistic & TB1 & TB2 & Decision & t-statistic & TB1 & TB2 & Decision \\
\hline Ln(GDPPC) & 2.123 & 1981 & 1993 & $\mathrm{I}(0)$ & -2.123 & 1985 & 1996 & $\mathrm{I}(0)$ \\
\hline $\mathrm{D}(\mathrm{Ln}(\mathrm{GDPPC}))$ & -5.768 & 1977 & 1981 & $\mathrm{I}(1)$ & -4.535 & 1977 & 1989 & $\mathrm{I}(0)$ \\
\hline $\mathrm{Ln}(\mathrm{PECPC})$ & -0.918 & 1983 & 1993 & $\mathrm{I}(0)$ & -2.529 & 1985 & 1995 & $\mathrm{I}(0)$ \\
\hline $\mathrm{D}(\mathrm{Ln}(\mathrm{PECPC}))$ & -7.697 & 1984 & 1988 & $\mathrm{I}(1)$ & -7.168 & 1987 & 1998 & $\mathrm{I}(1)$ \\
\hline $\operatorname{Ln}\left(\mathrm{CO}{ }_{2} \mathrm{PC}\right)$ & -1.837 & 1976 & 1983 & $\mathrm{I}(0)$ & -2.640 & 1983 & 1992 & $\mathrm{I}(0)$ \\
\hline $\mathrm{D}\left(\mathrm{Ln}\left(\mathrm{CO}_{2} \mathrm{PC}\right)\right)$ & -9.253 & 1976 & 1999 & $\mathrm{I}(1)$ & -6.596 & 1975 & 1998 & $\mathrm{I}(1)$ \\
\hline
\end{tabular}

Note: $5 \%$ critical value for $\mathrm{IO}$ and $\mathrm{AO}$ are -5.490 and -5.490 respectively.

Table-4: Clemente-Montanes-Reyes Unit Root Test Two Structural Breaks

\begin{tabular}{|c|c|c|c|c|c|}
\hline \multicolumn{6}{|c|}{$\begin{array}{l}\text { Panel 1: } \\
\text { Cointegration test- J [Trend assumption: Line } \\
\text { Unrestricted Cointegration Rank Test (Trace) }\end{array}$} \\
\hline $\mathrm{H}_{0}$ & $\mathrm{H}_{\mathrm{a}}$ & Eigenvalue & Trace Statistic & $5 \%$ Critical Value & Prob.** \\
\hline None* & At most 1 & 0.572113 & 54.62906 & 42.91525 & 0.0023 \\
\hline At most 1 & At most 2 & 0.393374 & 25.76656 & 25.87211 & 0.0515 \\
\hline At most 2 & At most 3 & 0.227403 & 8.771928 & 12.51798 & 0.1949 \\
\hline \multicolumn{6}{|c|}{ Unrestricted Cointegration Rank Test (Maximum Eigenvalue) } \\
\hline $\mathrm{H}_{\circ}$ & $\mathrm{H}_{\mathrm{a}}$ & Eigenvalue & Max-Eigen Statistic & $5 \%$ Critical Value & Prob.** \\
\hline None ${ }^{*}$ & At most 1 & 0.572113 & 28.86250 & 25.82321 & 0.0193 \\
\hline At most 1 & At most 2 & 0.393374 & 16.99463 & 19.38704 & 0.1077 \\
\hline At most 2 & At most 3 & 0.227403 & 8.771928 & 12.51798 & 0.1949 \\
\hline \multicolumn{6}{|c|}{$\begin{array}{l}\text { Panel 2: Cointegrating rank Tests- Lütkepohl, Saikkonen, and Trenkler (2004): Endogenously determined break date (1975) an } \\
\text { trend assumption is linear deterministic trend (restricted) lags interval (in first differences): } 1 \text { to 3] }\end{array}$} \\
\hline $\mathrm{H}_{\mathrm{o}}$ & $\mathrm{H}_{\mathrm{a}}$ & Eigenvalue & Trace Statistic & $5 \%$ Critical Value & $1 \%$ Critical Value \\
\hline None & At most 1 & 0.5830443 & 25.57 & 28.45 & 33.76 \\
\hline At most 1 & At most 2 & 0.2675000 & 9.03 & 15.83 & 19.85 \\
\hline At most 2 & At most 3 & 0.0140074 & 0.50 & 6.79 & 10.04 \\
\hline
\end{tabular}

Note: (1)* denotes rejection of the hypothesis at the 0.05 level and ${ }^{* *}$ MacKinnon-Haug-Michelis (1999) p-values; (2) Critical values of Lütkepohl, Saikkonen, and Trenkler (2004) test are from Trenkler (2003).

Source: Author's calculation

Table 5: Cointegration tests

\begin{tabular}{|l|l|l|l|}
\hline \multicolumn{4}{|l|}{ VEC Granger Causality Short Run/Block Exogeneity (Wald test/ $\left.X^{2}\right)$} \\
\hline \multirow{2}{*}{ Independent variables } & Dependent variables & \multicolumn{2}{l|}{$\operatorname{Ln}\left(\mathrm{CO}_{2} \mathrm{PC}\right)$} \\
\cline { 2 - 4 } & $\mathrm{Ln}(\mathrm{GDPPC})$ & $\mathrm{Ln}(\mathrm{PECPC})$ & 5.673291 \\
\hline $\mathrm{Ln}(\mathrm{GDPPC})$ & ----- & $10.37870^{* *}$ & 2.789826 \\
\hline $\mathrm{Ln}(\mathrm{PECPC})$ & 2.012965 & ---- & ------ \\
\hline $\mathrm{Ln}\left(\mathrm{CO}_{2} \mathrm{PC}\right)$ & $10.05588^{* *}$ & 4.666536 & 11.82430 \\
\hline Joint hypothesis & $15.35898^{* *}$ & 11.00509 & \\
\hline
\end{tabular}

Note: (1) $\mathrm{Ln}\left(\mathrm{CO}_{2} \mathrm{PC}\right)$ denotes log of $\mathrm{CO}_{2}$ emission per capita; $\mathrm{Ln}(\mathrm{PECPC})$ denotes log of primary energy consumption per capita; $\mathrm{Ln}(\mathrm{GDPPC})$ denotes $\log$ of Gross domestic product per capita. (2) *, and ${ }^{* *}$ denotes significance at the $1 \%$, and $5 \%$ levels, respectively.

Source: Author's calculation

Table 6: VAR Engle-Granger causality analysis

static framework. Variance Decomposition (VDs) and Impulse Response Functions (IRFs) were used for examining the causality in the dynamic frameworks.

From the analysis of unit root tests it was found that even by incorporating endogenously determined two structural breaks in the data all variables are stationary in their first difference form. Cointegration analysis with incorporation of structural breaks shows that variables under consideration are not cointegrated. Static Granger causality tests show that causality runs from GDP to primary energy consumption and $\mathrm{CO}_{2}$ emissions to GDP and energy consumption. Dynamic causality analysis analyzed through IRFs shows evidence of a bidirectional causal relationship between the test variables, while dynamic analysis analyzed through VDs show evidence of unidirectional causality running from GDP to energy 


\section{Accumulated Response to Generalized One S.D. Innovations \pm 2 S.E.}

Accumulated Response of LNGDPPC to LNGDPPC

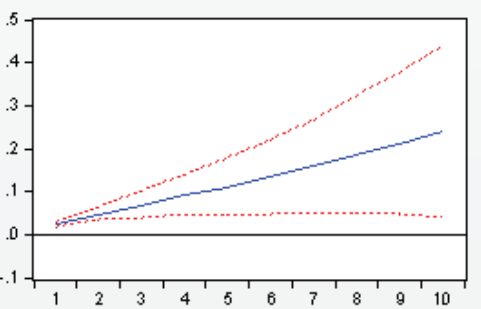

Accumulated Response of LNPECPC to LNGDPPC

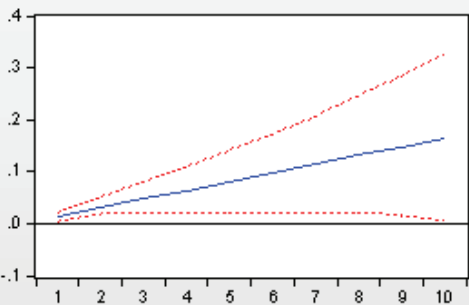

Accumulated Response of LNCO2PC to LNGDPPC

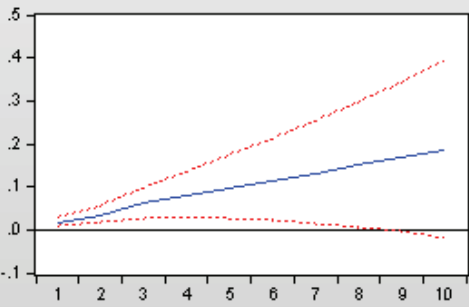

Accumulated Response of LNGDPPC to LNPECPC

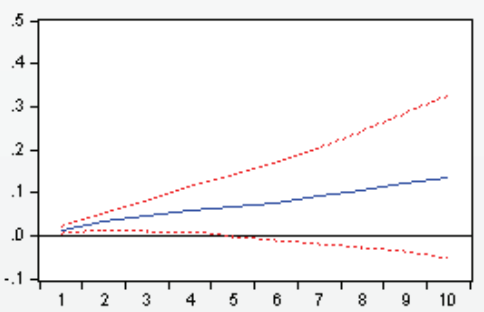

Accumulated Response of LNPECPC to LNPECPC

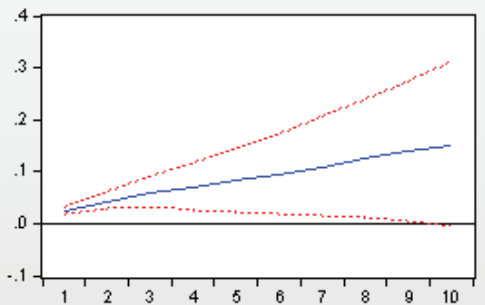

Accumulated Response of LNCO2PC to LNPECPC

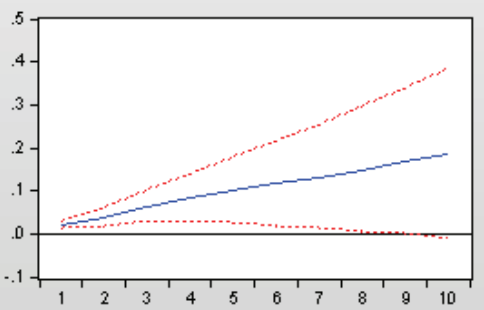

Accumulated Response of LNGDPPC to LNCO2PC

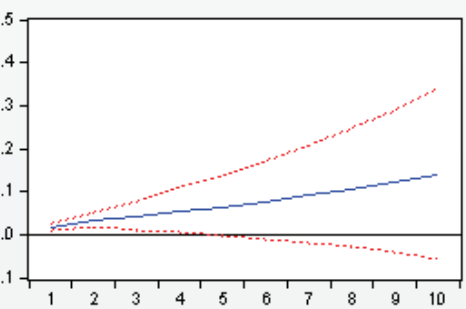

Accumulated Response of LNPECPC to LNCO2PC

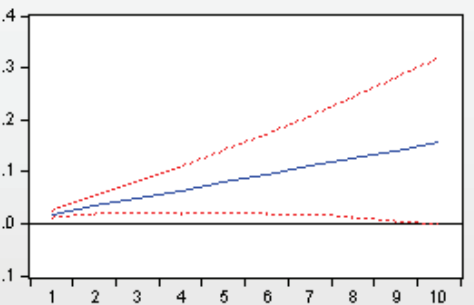

Accumulated Response of LNCO2PC to LNCO2PC

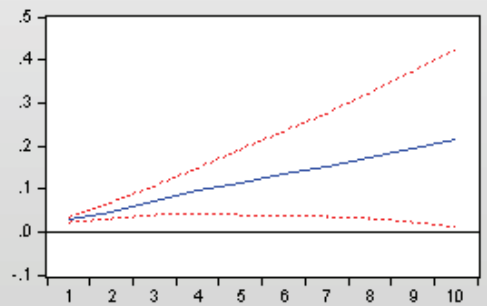

Figure 2: IRFs analysis

\begin{tabular}{|c|c|c|}
\hline \multicolumn{2}{|c|}{ VEC Lag Exclusion Wald Tests (Chi-squared test statistics for lag exclusion) for Dlag 2. (Joint test) } & P-Value \\
\hline \multicolumn{2}{|c|}{$28.25411^{* * *}$} & [0.000865] \\
\hline \multicolumn{3}{|c|}{ VEC Residual Serial Correlation LM Tests } \\
\hline 1lag & 5.805719 & 0.7592 \\
\hline $2 \mathrm{lag}$ & 15.08162 & 0.0887 \\
\hline 3lag & 9.387007 & 0.4023 \\
\hline \multicolumn{3}{|c|}{ VEC Residual Normality Tests-Joint J-B test (Orthogonalization: Residual Covariance (Urzua) } \\
\hline 26.21123 & & 0.3964 \\
\hline \multicolumn{3}{|c|}{ VEC Residual Heteroskedasticity Tests (Joint test of Chi- square) } \\
\hline \multicolumn{2}{|c|}{110.7624} & 0.4084 \\
\hline
\end{tabular}

Note: $(1)^{*},{ }^{* *}$ and ${ }^{* * *}$ denotes significant at $1 \%, 5 \%$, and $10 \%$ level respectively.

Source: Author's calculation

Table 7: Diagnostic checks analysis

\section{Null hypotheses}

Real GDP per capita does not cause Primary energy consumption per capita

WALD test

$\mathrm{CO}_{2}$ emissions per capita do not cause Primary energy consumption per capita

$21.01522^{*}$

Primary energy consumption per capita does not cause real GDP

$\mathrm{CO}_{2}$ emissions per capita do not cause real GDP per capita

$16.53501^{*}$

GDP does not cause $\mathrm{CO}_{2}$ emissions per capita

Primary energy consumption per capita does not cause $\mathrm{CO}_{2}$ emissions

$13.83537^{*}$

Note: $(1){ }^{*}$, and ${ }^{* *}$ denotes significance at the $1 \%$, and $5 \%$, levels respectively.

Source: Author's calculation

Table 8: TY and DL Engle-Granger causality analysis

consumption and $\mathrm{CO}_{2}$ emissions. Thus, there exist conflicting findings from the IRFs and VDs. However, it can be concluded that there is strong evidence of unidirectional causality running from GDP to energy 
consumption, while energy consumption does not precede economic growth, i.e., GDP. GDP explains most of the forecast error variance of $\mathrm{CO}_{2}$ emissions, implying that the focus of policymakers should be on sustainability and social welfare rather than per capita income. There are a number of studies that suggest environmental degradation, including air and noise pollution, has a negative impact on life satisfaction (Ferrer-i-Carbonell and Gowdy (2007), Di Tella and MacCulloch (2008), Van Praag and Baarsma (2005), Welsch $(2002,2006)$, Rehdanz and Maddison (2008), Smyth, Mishra and Qian (2008)). On the other hand, a persistent decline in environmental quality may generate negative externalities for the economy through reducing health, human capital, and hence, productivity in the long-run (Ang (2008)). Energy consumption is not a source of economic growth, hence Indian policy makers can directly cut the consumption of primary energy.

One of the limitations of this study is that the analysis was carried out on aggregate level data. Different industries have different intensities of electricity use, therefore it would be more appropriate to perform analyses at disaggregate levels in order to acquire more insight so that appropriate policy decisions can be used in the face of the deregulation of the Indian economy. A second direction for future research would be to examine the causal relationship between economic growth, pollution emissions, and other potentially relevant variables such as automobile use, health expenditure, and urbanization. A third direction would be to carry out nonlinear Granger-causality analysis to check the robustness of the linear causality results. $[$.

\section{References}

Akarca, A.T., Long, T.V. 1980. On the relationship between energy and GNP: A reexamination. Journal of Energy and Development 5: 32631.

Altinay, G., Karagol, E. 2005. Electricity consumption and economic growth: Evidence from Turkey. Energy Economics 27: 849-56.

Ang, J.B. 2007. $\mathrm{CO}_{2}$ emissions, energy consumption and output in France. Energy Policy 35: 4772-4778.

Ang, J.B. 2008. Economic development, pollutant emissions and energy consumption in Malaysia. Journal of Policy Modelling 30: 271278.

Aqeel, A., Butt, S. 2001. The relationship between energy consumption and economic growth in Pakistan. Asia Pacific Development Journal 8: 101-10.

Arranz, M. A., Escribano, A. 2000. Cointegration testing under structural breaks: A robust extended error correction model. Oxford Bulletin of Economics and Statistics 62: 23-52.
Brooks, Chris. 2008. Introductory Econometrics for Finance. NewYork, Cambridge University Press.

Campos, J., Ericsson, N.R., Hendry, D. F. 1996. Cointegration tests in the presence of structural Breaks. Journal of Econometrics 70: 187-220.

Chang,Y. and Wong, J. F. 2001. Poverty, energy and economic growth in Singapore. Working Paper, Dept. of Economics, National University of Singapore. P. 37

Cheng, B. S. 1995. An investigation of cointegration and causality between energy consumption and economic growth. Journal of Energy and Development 21: 73-84.

Cheng, B. S. 1999. Causality between energy consumption and economic growth in India: An application of cointegration and error correction modeling. Indian Economic Review 34: 39-49.

Cheng, B. S. and Lai, T. W. 1997. An investigation of cointegration and causality between energy consumption and economic activity in Taiwan. Energy Economics 19: 345-444.

Clemente, J., Montanes, A., Reyes, M. 1998. Testing for a unit root in variables with a double change in the mean. Economics Letters 59: 175182.

Di Tella, R. and MacCulloch, R. 2008. Gross national happiness as an answer to the Easterlin paradox? Journal of Development Economics 86: 22-42.

Dolado, J.J., Lütkepohl, H. 1996. Making the Wald test work for cointegrated VAR systems. Econometric Theory 15: 369-386.

Fati, K., Oxley, L., Scrimgeour, F.G. 2004. Modeling the causal relationship between energy consumption and GDP in New Zealand, Australia, India, Indonesia, the Philippines and Thailand. Mathematics and Computers in Simulation 64: 431-445.

Ferrer-i-Carbonell, A. and Gowdy, J.M. 2007. Environmental degradation and happiness. Ecological Economics 60: 509-516.

Ghali, K.H., El-Sakka, M.I.T. 2004. Energy and output growth in Canada: A multivariate cointegration analysis. Energy Economics 26: 225-38.

Ghosh, S. 2002. Electricity consumption and economic growth in India. Energy Policy 30: 125-9.

Glasure, Y.U. 2002. Energy and national income in Korea: Further evidence on the role of omitted variables. Energy Economics 24: 355-65.

Granger, C.W.J. 1969. Investigation of causal relations by econometric models and cross-spectral methods. Econometrica 37: 42438.

Gregory, A.W., Hansen, B.E. 1996. Residual-based tests for cointegration in models with regime shifts. Journal of Econometrics 70: 99-126.

Halicioglu, F. 2009. An econometric study of $\mathrm{CO}_{2}$ emissions, energy consumption, income and foreign trade in Turkey. Energy Policy 37: 699702.

Hansen, B. E. 1992. Tests for parameter instability in regressions with I(1) processes. Journal of Business and Economic Statistics 10: 321-335.

Harris, R. 1995. Using Cointegration Analysis in Econometric Modeling. London, Prentice Hall.

Hatemi, A., and Irandoust, M. 2005. Energy consumption and economic growth in Sweden: A leveraged bootstrap approach, 19652000. International Journal of Applied Econometrics and Quantitative Studies 4: 1-20.

Hwang, D., Gum, B. 1992. The causal relationship between energy and GNP: The case of Taiwan. Journal of Energy and Development 12: 219-26. 
Inoue, A. 1999. Tests of cointegrating rank with a trend-break. Journal of Econometrics 90: 215-237.

Johansen, S. 1988. Statistical analysis of cointegration vectors. Journal of Economic Dynamics and Control 12: 231-254.

Johansen, S. 1991. Estimation and hypothesis testing of cointegration vectors in Gaussian vector autoregressive models. Econometrica 59: 1551-80.

Johansen, S., Juselius, K. 1990. Maximum likelihood estimation and inference on cointegration with applications to money demand. Oxford Bulletin of Economics and Statistics 52: 169-210.

Johansen, S., Mosconi, R., Nielsen, B. 2000. Cointegration analysis in the presence of structural breaks in the deterministic trend. Econometrics Journal 3: 216-249.

Johansen, S., Nielsen, B. 1993. Manual for the simulation program DisCo. Institute of Mathematical Statistics, University of Copenhagen. Available at http://math.ku.dk/ sjo/disco/disco.ps.

Jumbe, C.B.L. 2004. Cointegration and causality between electricity consumption and GDP: Empirical evidence from Malawi. Energy Economics 26: 61-68.

Kennedy, Peter. 2003. A Guide to Econometrics. UK, Oxford: Blackwell Publishers Ltd.

Lee, C.C., Chang, C.P. 2005. Structural breaks, energy consumption, and economic growth revisited: Evidence from Taiwan. Energy Economics 27: 857-72.

Liew, K.S. 2004. Which lag length selection criteria should we employ? Economics Bulletin 3(33): 1-9.

Lütkepohl, H., Saikkonen, P., Trenkler, C. 2003. Comparison of tests for the cointegrating rank of a VAR process with a structural shift. Journal of Econometrics 113: 201-229.

Lütkepohl, H., Saikkonen, P., Trenkler, C. 2004. Testing for the cointegrating rank of a VAR process with level shift at unknown time. Econometrica 72: 647-662.

Mackinnon, J. G. 1996. Numerical distribution functions for unit root and cointegration test. Journal of Applied Econometrics 11: 601-618.

Mackinnon, J. G., Alfred A. Haug, and Leo Michelis. 1999. Numerical distribution functions of likelihood ratio test for cointegration. Journal of Applied Econometric 14: 563-577.

Masih, A.M.M., Masih, R. 1996. Energy consumption, real income and temporal causality: Results from a multi-country study based on cointegration and error-correction modeling techniques. Energy Economics 18: 165-83.

Masih, A.M.M., Masih, R. 1997. On the temporal causal relationship between energy consumption, real income, and prices: Some new evidence from Asian-energy dependent NICs based on a multivariate cointegration/vector error correction approach. Journal of Policy Modeling 19: 417-40.

Mollick, A.V. 2009. Employment responses of skilled and unskilled workers at Mexican maquiladoras: The effects of external factors. World Development 37(7): 1285-1296.

Moritomo, R., Hope, C. 2004. The impact of electricity supply on economic growth in Sri Lanka. Energy Economics 26: 77-85.

$\mathrm{Ng}$, Serena, and Pierre Perron. 2001. Lag length selection and the construction of unit root tests with good size and power. Econometrica 69: 1519-1554.

Oh, W., Lee, K. 2004. Causal relationship between energy consumption and GDP revisited: The case of Korea 1970-1999. Energy Economics 26: 51-9.
Paul, Shyamal \& Rabindra N. Bhattacharya. 2004. Causality between energy consumption and economic growth in India: A note on conflicting results. Energy Economics 26: 977-83.

Phillips, P., and Pierre Perron. 1988. Testing for a unit root in time series regression. Biometrica 75: 335-346.

Rehdanz, K. and Maddison, D. 2008. Local environmental quality and life-satisfaction in Germany. Ecological Economics 64: 787-797.

Saikkonen, P., Lütkepohl, H. 2000. Testing for the cointegrating rank of a VAR process with structural shifts. Journal of Business and Economic Statistics 18: 451-464.

Sari, R. and Soytas, U. 2009. Are global warming and economic growth combatable? Evidence from Five OPEC countries. Applied Energy 86: 1887-1893.

Schwert, G. W. 1989. Tests for unit roots: A monte carlo investigation. Journal of Business and Economic Statistics 7: 147-160.

Seo, B. 1998. Tests for structural change in cointegrated systems. Econometric Theory 14: 222-259.

Shahbaz, Muhammad, Tang, C. F., Shabbir, M. S. 2011. Electricity consumption and economic growth nexus in Portugal using cointegration and causality approaches, Energy Policy (in press).

Shiu, A., Lam, L. P. 2004. Electricity consumption and economic growth in China. Energy Policy 30: 47-54.

Smyth, R., Mishra, V. and Qian, X. 2008. The environment and wellbeing in urban China. Ecological Economics 68: 547-555.

Soytas, U. and Sari, R. 2009. Energy consumption, economic growth and carbon emissions: challenges faced by an EU candidate member Ecological Economics 68: 1667-1675.

Soytas, U., Sari, R. 2003. Energy consumption and GDP: Causality relationship in G-7 countries and emerging markets. Energy Economics 25: 33- 37.

Soytas, U., Sari, R. and Ewing, B.T. 2007. Energy consumption, income and carbon emissions in the United States. Ecological Economics 62: 482-489.

Stern, D.I. 1993. Energy growth in the USA: A multivariate approach. Energy Economics 15: 137-150.

Tiwari, Aviral K. 2011a. Energy consumption, $\mathrm{CO}_{2}$ Emission and economic growth: Evidence from India. Journal of International Business and Economy 12: (Forthcoming).

Tiwari, Aviral K. 2011b. Energy consumption, $\mathrm{CO}_{2}$ emission and economic growth: A revisit of the evidence from India. Applied Econometrics and International Development 11-2: (Forthcoming).

Toda, H.Y. 1995. Finite sample performance of likelihood ratio tests for cointegrating ranks in vector autoregressions. Econometric Theory 11: 1015- 1032.

Toda, H.Y., Yamamoto, T. 1995. Statistical inference in vector autoregressions with possibly integrated processes. Journal of Econometrics 66: 225-250.

Trenkler, C. 2003. A new set of critical values for systems cointegration tests with a prior adjustment for deterministic terms. Economics Bulletin 3: 1-9.

Urzua, C. M. 1997. Omnibus test for multivariate normality based on a class of maximum entropy distributions. Advances in Econometrics 12: 341-358.

Van Praag, B.M.S. and Baarsma, B.E. 2005. Using happiness surveys to value intangibles: The case of airport noise. Economic Journal 115: 224-246. 
Welsch, H. 2002. Preferences over prosperity and pollution: environmental valuation based on happiness surveys. Kyklos 55: 473494.

Welsch, H. 2006. Environment and happiness: Valuation of air pollution using life satisfaction data. Ecological Economics 58: 801-813.

Wolde-Rufael, Y. 2004. Disaggregated industrial energy consumption and GDP: The case of Shanghai, 1952-1999. Energy Economics 26: 69- 75.

Yoo, S.H. 2005. Electricity consumption and economic growth:
Evidence from Korea. Energy Policy 33: 1627- 1632.

$\mathrm{Yu}$, E.S.H. Hwang, B. 1984. The relationship between energy and GNP: Further results. Energy Economics 6: 186-90.

Zhang, X.P. and Cheng, X.M. 2009. Energy consumption, carbon emissions and economic growth in China. Ecological Economics 68: 2706-2712.

Zivot, E., Andrews, D. 1992. Further evidence on the great crash, the oil-price shock, and the unit-root hypothesis. Journal of Business and Economic Statistics 10: 251-270.

\section{Appendix 1: Plots of ZA and CMR tests of structural breaks in the unit root}

\section{ZA: When break occurs in intercept}
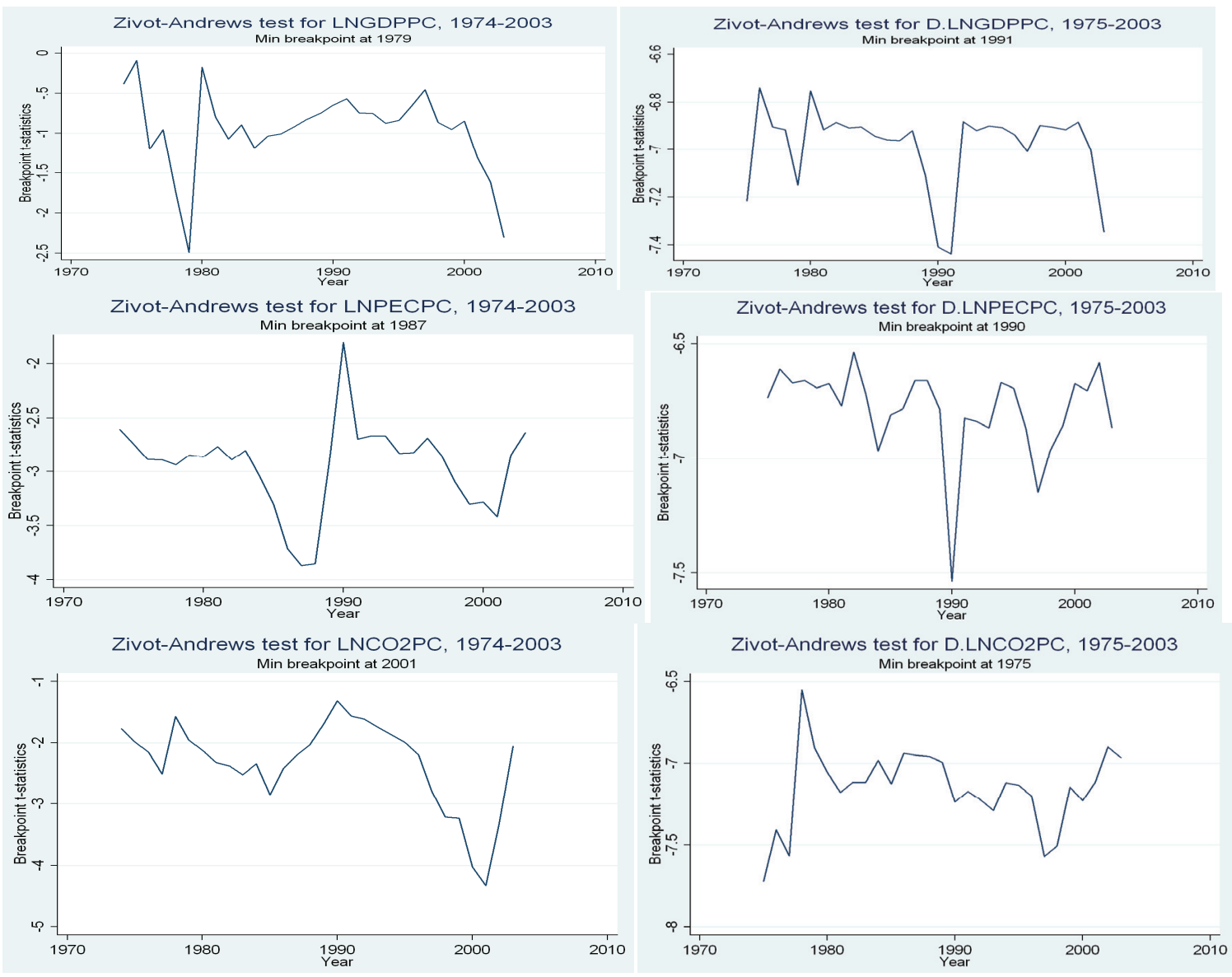


\section{ZA: When break occurs in trend}
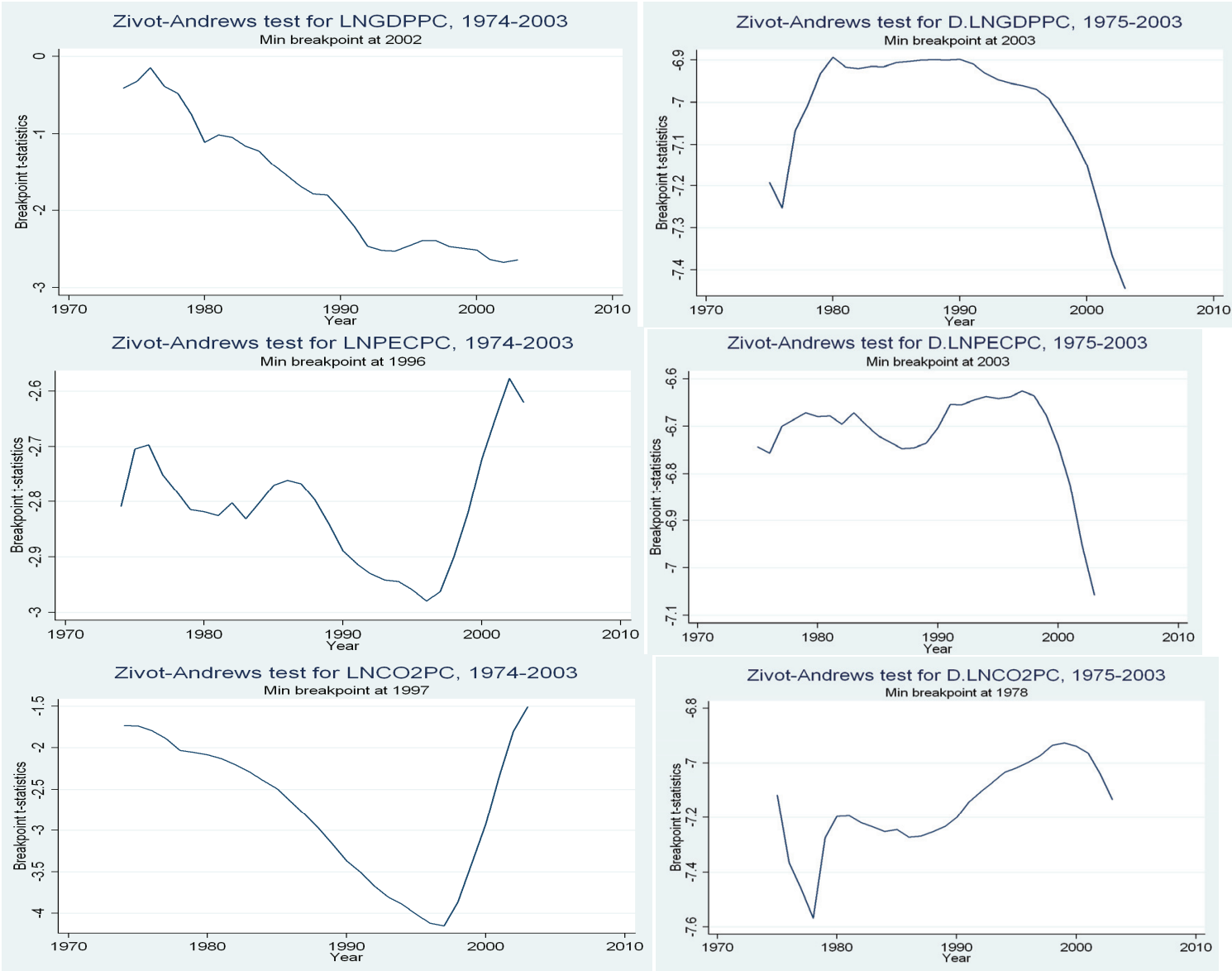

\section{ZA: When break occurs in intercept and trend}
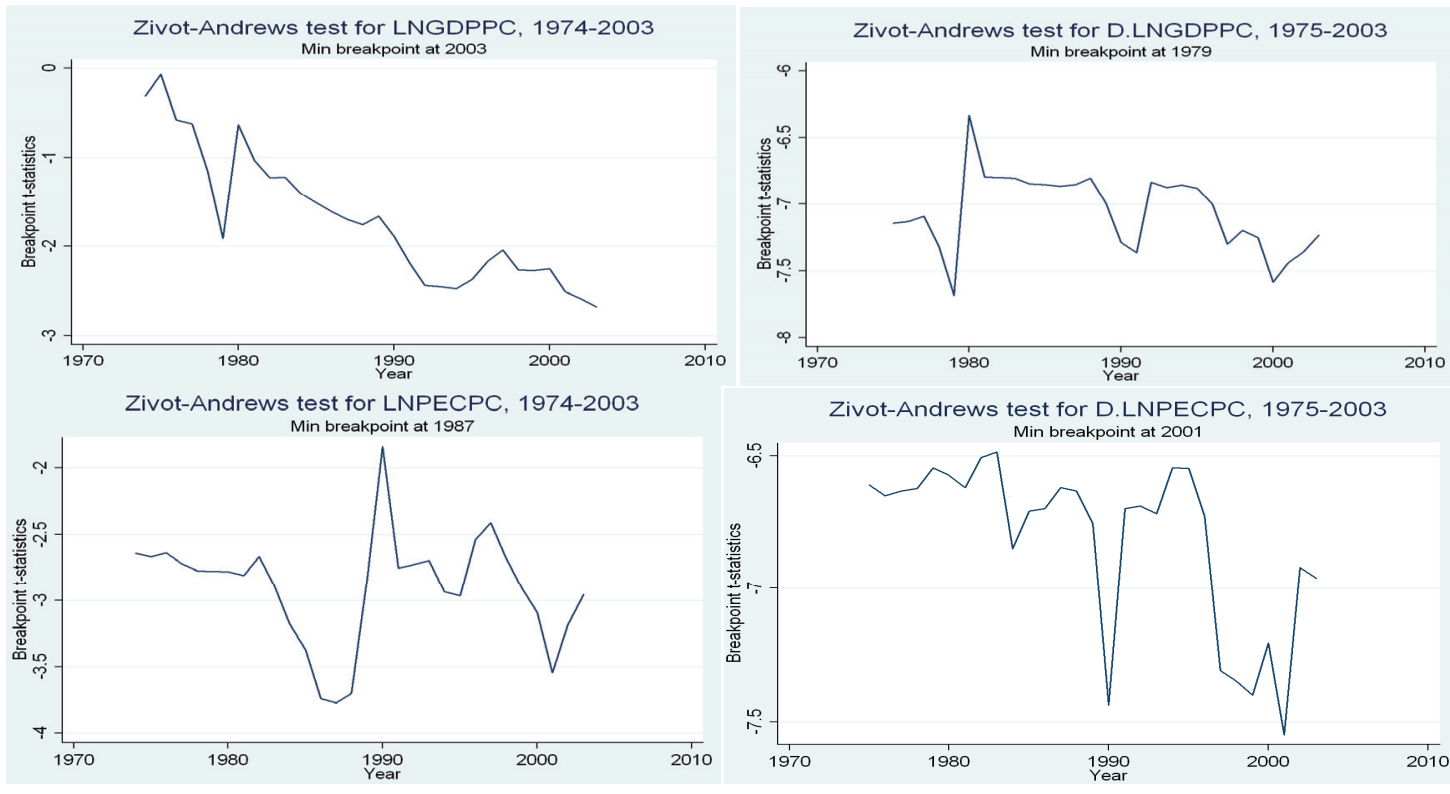

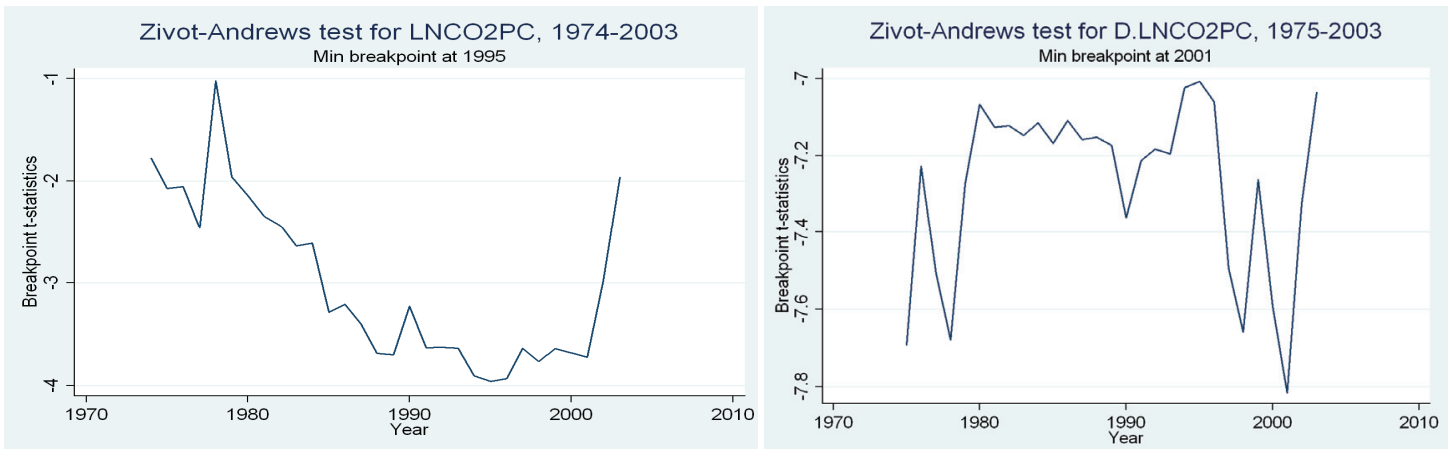

\section{CMR-IO type test: One break in level and first difference form series}

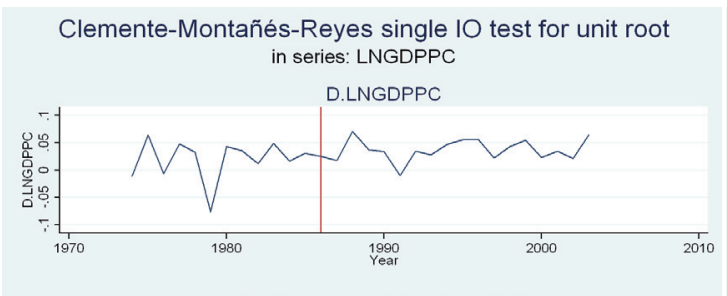

Clemente-Montañés-Reyes single IO test for unit root in series: D.LNGDPPC
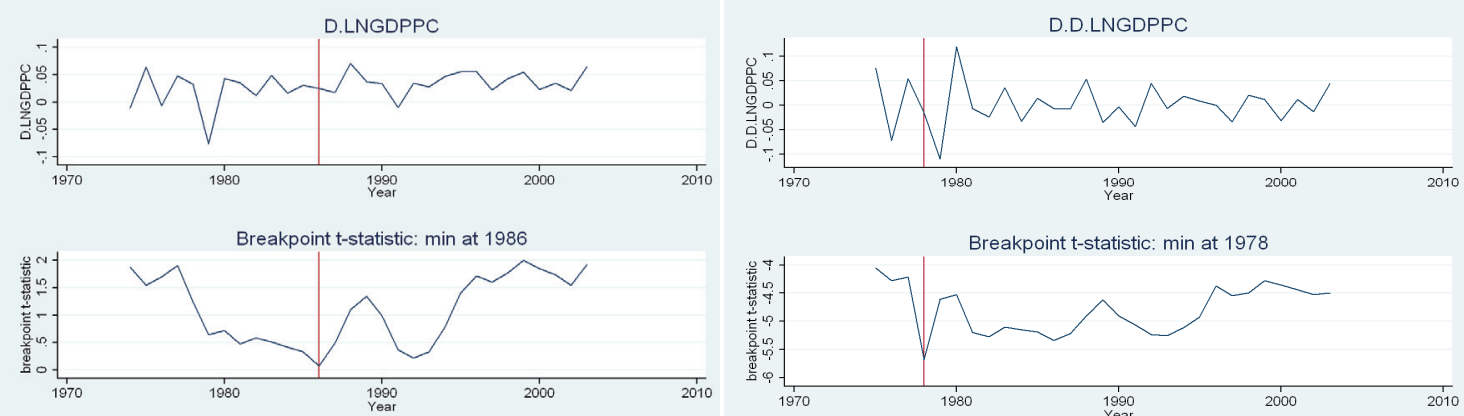

Clemente-Montañés-Reyes single $1 O$ test for unit root in series: $L N P E C P C$

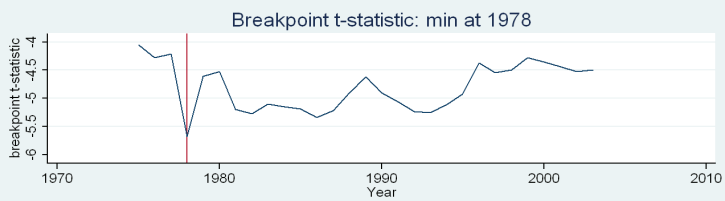

Clemente-Montañés-Reyes single $1 O$ test for unit root in series: D.LNPECPC

D.LNPECPC
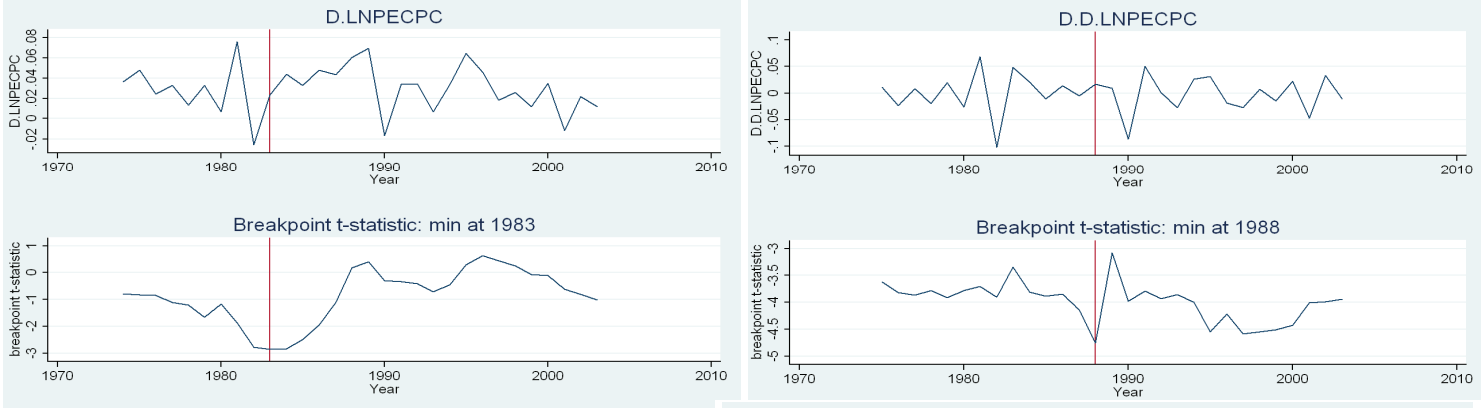

Clemente-Montañés-Reyes single 10 test for unit root in series: LNCO2PC

D.LNCO2PC
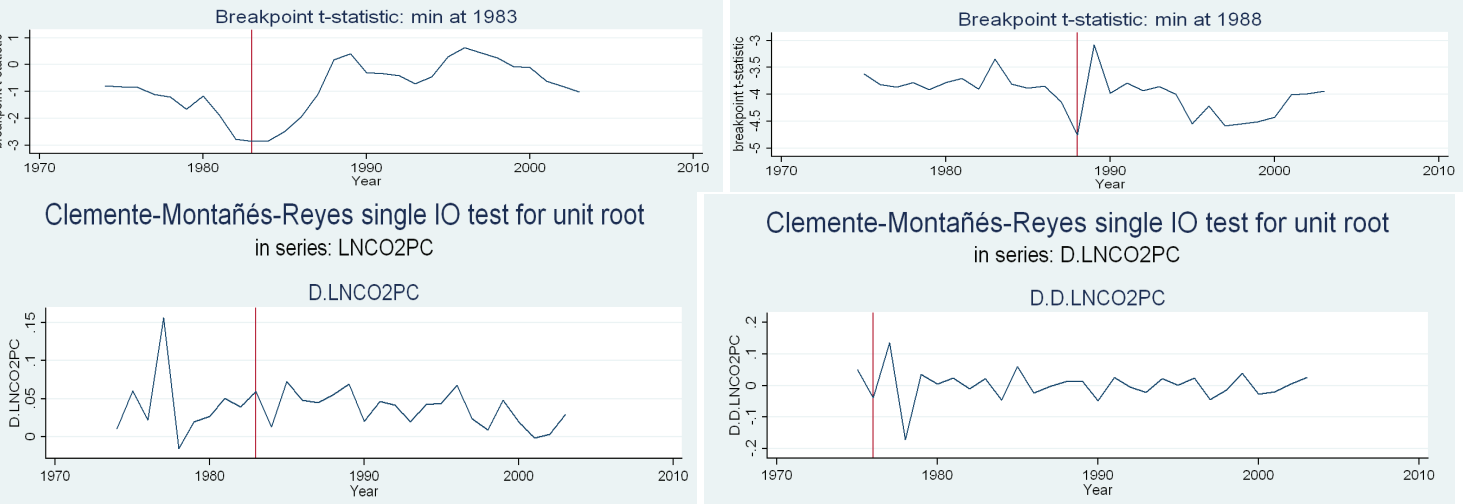

Clemente-Montañés-Reyes single 10 test for unit root in series: D.LNCO2PC
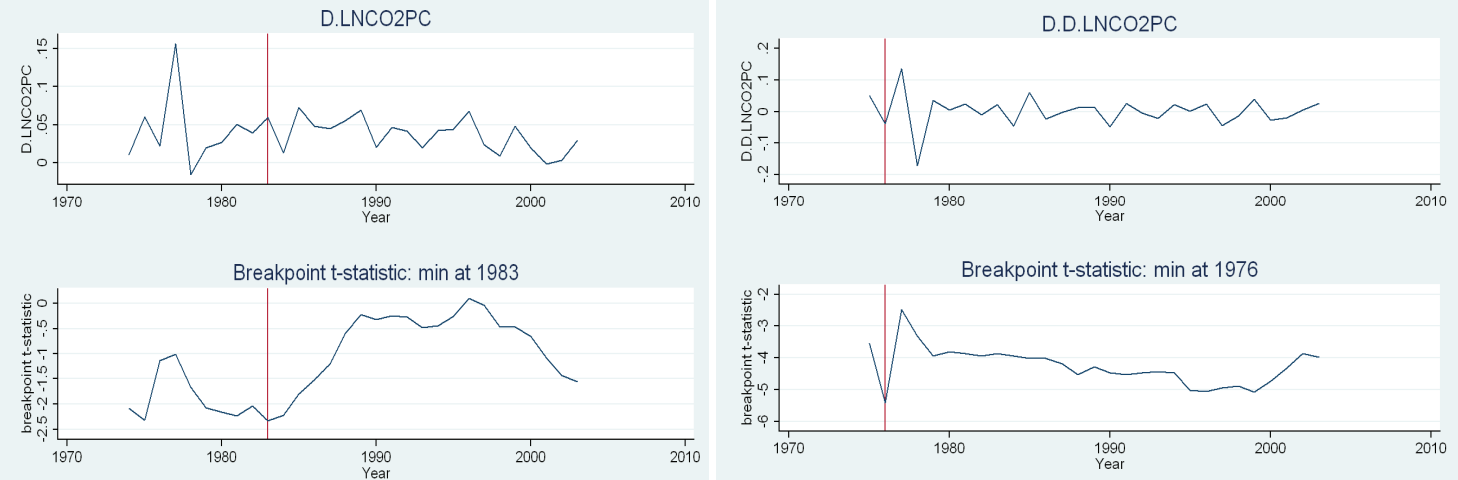

Breakpoint t-statistic: min at 1976

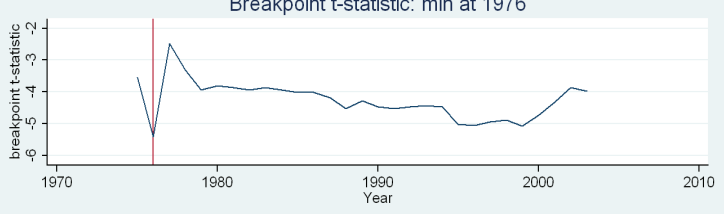




\section{CMR-IO type test: Two break in level and first difference form series}

Clemente-Montañés-Reyes double 10 test for unit root

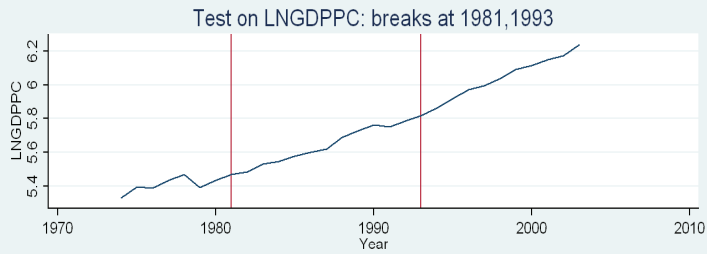

D.LNGDPPC

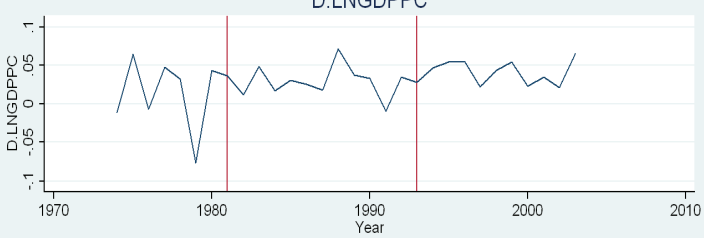

Clemente-Montañés-Reyes double $1 O$ test for unit root

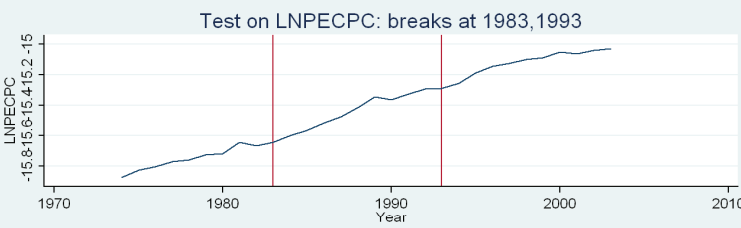

D.LNPECPC

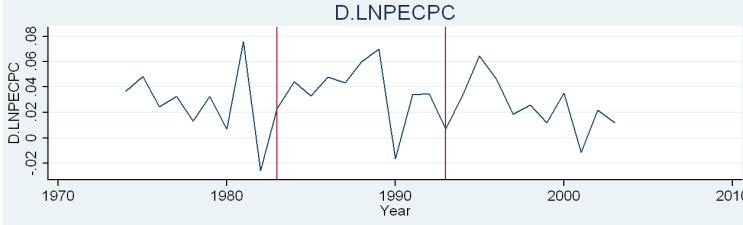

Clemente-Montañés-Reyes double 10 test for unit root

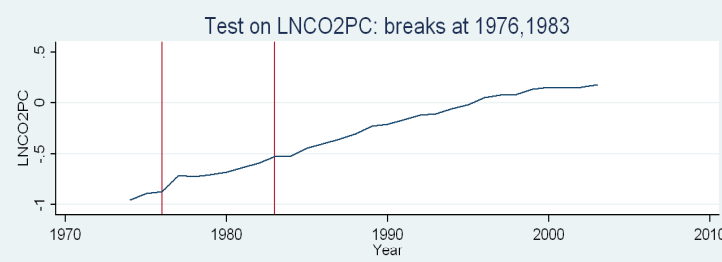

D.LNCO2PC

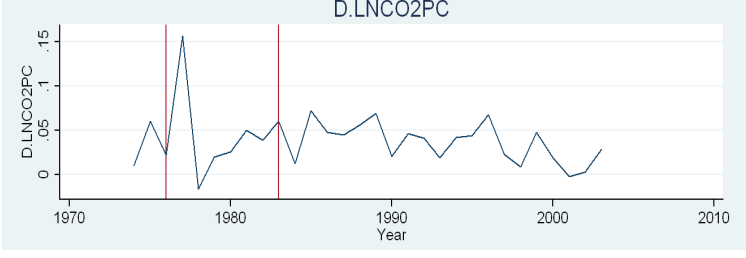

Clemente-Montañés-Reyes double 10 test for unit root

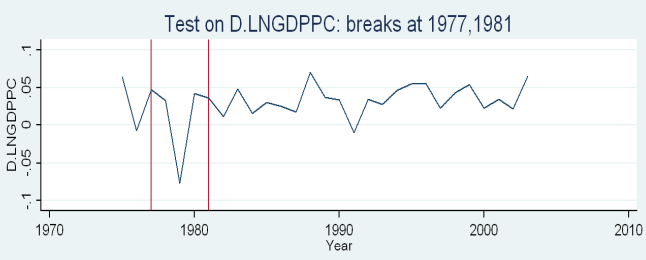

D.D.LNGDPPC

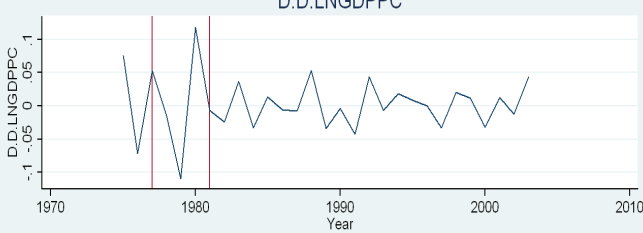

Clemente-Montañés-Reyes double 10 test for unit root

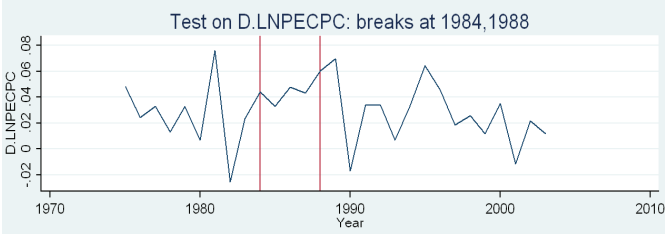

D.D.LNPECPC

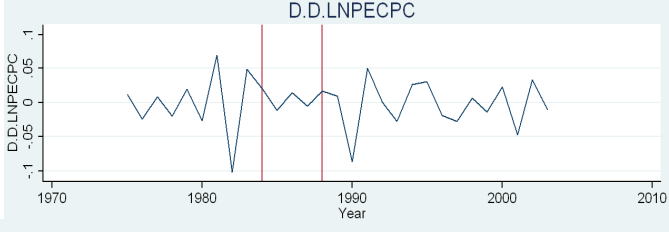

Clemente-Montañés-Reyes double 10 test for unit root

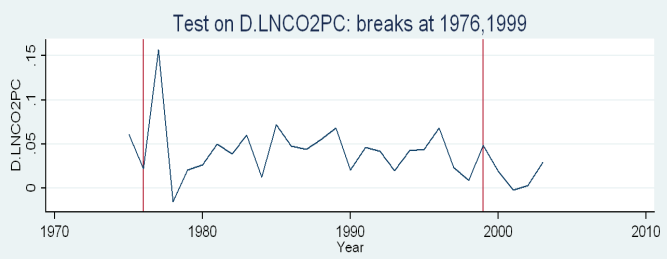

D.D.LNCO2PC

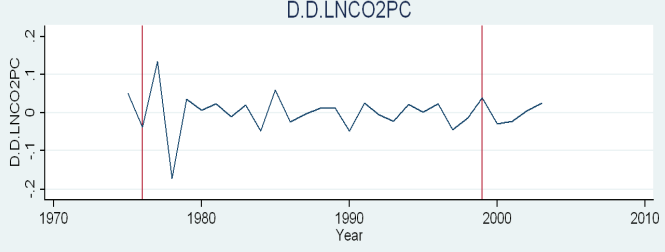




\section{CMR-AO type test: One break in level and first difference form series}

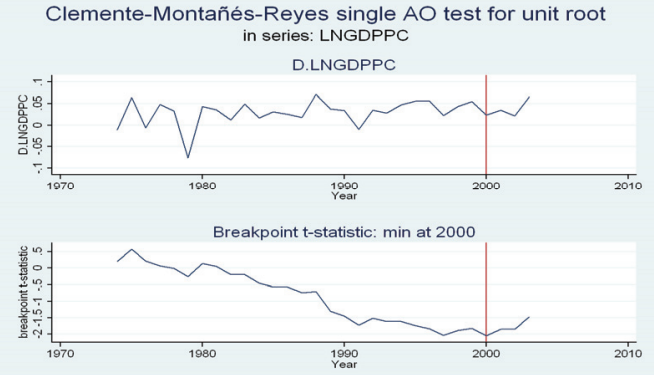

Clemente-Montañés-Reyes single $A O$ test for unit root in series: LNPECPC
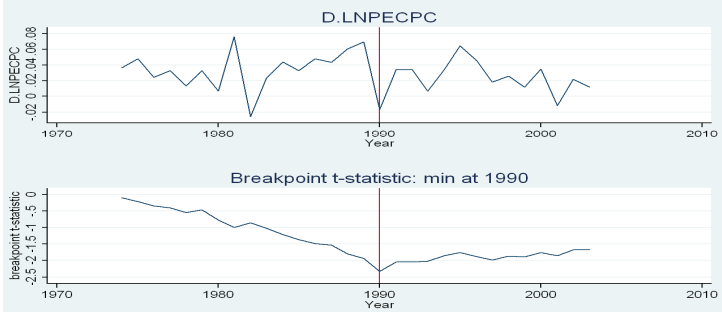

Clemente-Montañés-Reyes single $\mathrm{AO}$ test for unit root in series: $\mathrm{LNCO} 2 \mathrm{PC}$
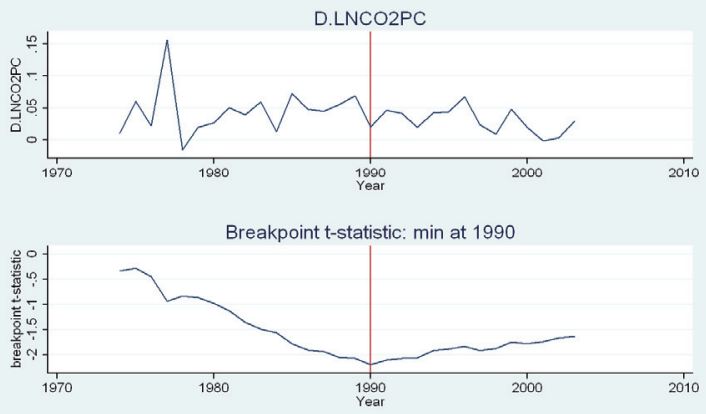

Clemente-Montañés-Reyes single AO test for unit root in series: D. LNGDPPC
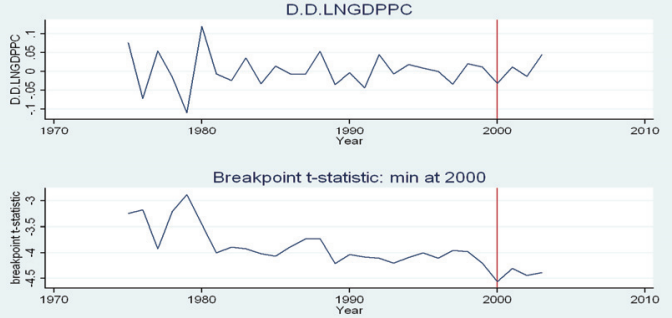

Clemente-Montañés-Reyes single $A O$ test for unit root in series: D. LNPECPC
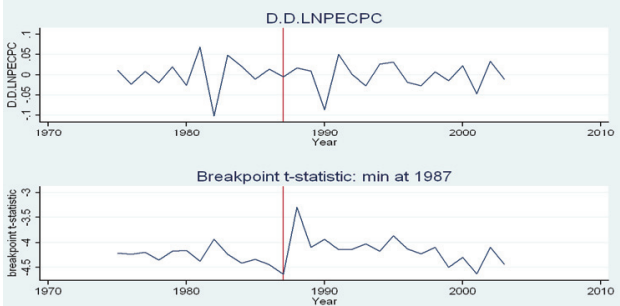

Clemente-Montañés-Reyes single $A O$ test for unit root in series: D.LNCO2PC D.D.LNCO2PC

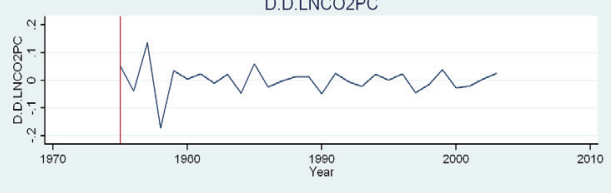

Breakpoint t-statistic: $\min$ at 1975

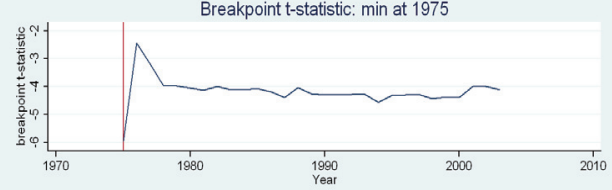

\section{CMR-AO type test: Two break in level and first difference form series}
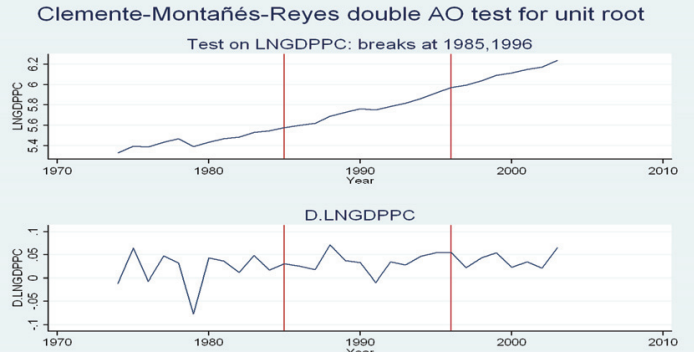

Clemente-Montañés-Reyes double AO test for unit root
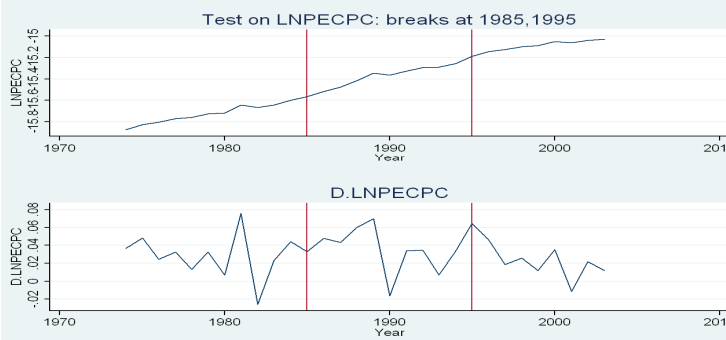

Clemente-Montañés-Reyes double AO test for unit root
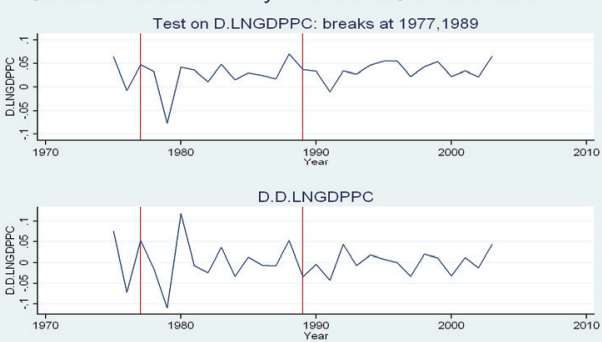

Clemente-Montañés-Reyes double AO test for unit root
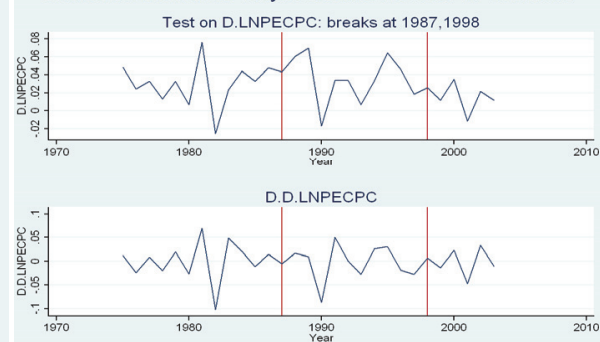

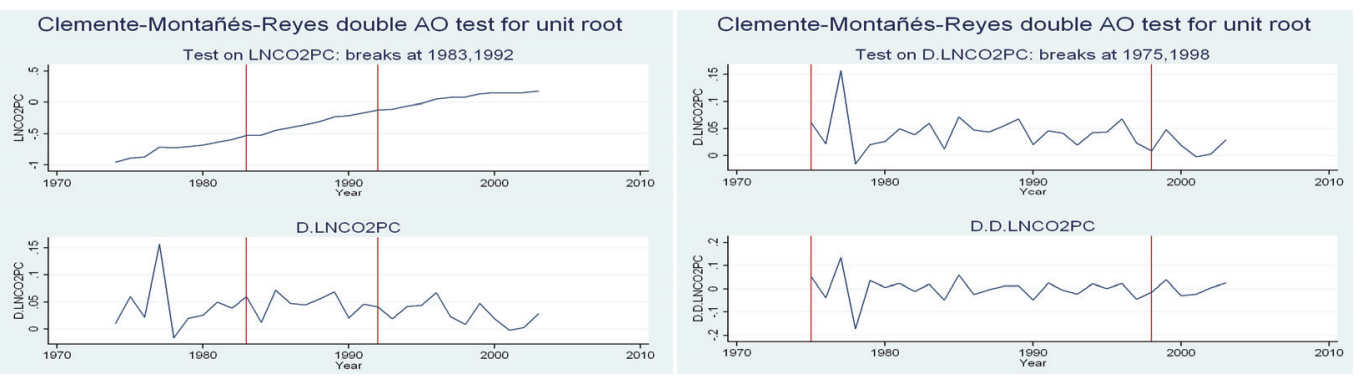

Appendix 2: Results of Variance Decompositions (VDs) analysis

\begin{tabular}{|c|c|c|c|c|}
\hline Period & S.E. & $\operatorname{Ln}(G D P P C)$ & $\operatorname{Ln}(\mathrm{PECPC})$ & $\operatorname{Ln}\left(\mathrm{CO}_{2} \mathrm{PC}\right)$ \\
\hline 1 & 0.023649 & $\begin{array}{l}100.0000 \\
(0.00000)\end{array}$ & $\begin{array}{l}0.000000 \\
(0.00000)\end{array}$ & $\begin{array}{l}0.000000 \\
(0.00000)\end{array}$ \\
\hline 2 & 0.033896 & $\begin{array}{l}96.97821 \\
(5.60373)\end{array}$ & $\begin{array}{l}3.017912 \\
(5.40714)\end{array}$ & $\begin{array}{l}0.003875 \\
(1.64589)\end{array}$ \\
\hline 3 & 0.041200 & $\begin{array}{l}91.90075 \\
(8.60393)\end{array}$ & $\begin{array}{l}2.117241 \\
(5.82539)\end{array}$ & $\begin{array}{l}5.982005 \\
(6.54274)\end{array}$ \\
\hline 4 & 0.047692 & $\begin{array}{l}93.51180 \\
(9.52964)\end{array}$ & $\begin{array}{l}1.819325 \\
(6.70987)\end{array}$ & $\begin{array}{l}4.668880 \\
(6.58109)\end{array}$ \\
\hline 5 & 0.051088 & $\begin{array}{l}93.73034 \\
(10.4379)\end{array}$ & $\begin{array}{l}1.990674 \\
(7.45079)\end{array}$ & $\begin{array}{l}4.278983 \\
(7.22562)\end{array}$ \\
\hline 6 & 0.056129 & $\begin{array}{l}94.49577 \\
(10.5622)\end{array}$ & $\begin{array}{l}1.812795 \\
(7.70588)\end{array}$ & $\begin{array}{l}3.691434 \\
(7.10392)\end{array}$ \\
\hline 7 & 0.061536 & $\begin{array}{l}95.38634 \\
(10.5360)\end{array}$ & $\begin{array}{l}1.514612 \\
(7.90171)\end{array}$ & $\begin{array}{l}3.099048 \\
(6.83340)\end{array}$ \\
\hline 8 & 0.066792 & $\begin{array}{l}95.58064 \\
(10.8404)\end{array}$ & $\begin{array}{l}1.285690 \\
(8.18933)\end{array}$ & $\begin{array}{l}3.133670 \\
(7.03312)\end{array}$ \\
\hline 9 & 0.072577 & $\begin{array}{l}95.93198 \\
(11.1191)\end{array}$ & $\begin{array}{l}1.101510 \\
(8.44613)\end{array}$ & $\begin{array}{l}2.966506 \\
(7.18827)\end{array}$ \\
\hline 10 & 0.077601 & $\begin{array}{l}96.21264 \\
(11.6007)\end{array}$ & $\begin{array}{l}0.964828 \\
(8.87591)\end{array}$ & $\begin{array}{l}2.822532 \\
(7.48609)\end{array}$ \\
\hline
\end{tabular}




\begin{tabular}{|c|c|c|c|c|}
\hline \multicolumn{5}{|c|}{ Variance Decomposition of $\operatorname{Ln}(\mathrm{PECPC})$ : } \\
\hline 1 & 0.023450 & $\begin{array}{l}30.73633 \\
(12.6502)\end{array}$ & $\begin{array}{l}69.26367 \\
(12.6502)\end{array}$ & $\begin{array}{l}0.000000 \\
(0.00000)\end{array}$ \\
\hline 2 & 0.032267 & $\begin{array}{l}53.35559 \\
(13.4107)\end{array}$ & $\begin{array}{l}46.63693 \\
(13.3282)\end{array}$ & $\begin{array}{l}0.007488 \\
(1.73710)\end{array}$ \\
\hline 3 & 0.037438 & $\begin{array}{l}57.96206 \\
(14.9978)\end{array}$ & $\begin{array}{l}41.31890 \\
(14.9984)\end{array}$ & $\begin{array}{l}0.719046 \\
(3.49750)\end{array}$ \\
\hline 4 & 0.040586 & $\begin{array}{l}63.45754 \\
(15.1056)\end{array}$ & $\begin{array}{l}35.52800 \\
(15.0411)\end{array}$ & $\begin{array}{l}1.014456 \\
(4.42327)\end{array}$ \\
\hline 5 & 0.044572 & $\begin{array}{l}66.43932 \\
(15.0676)\end{array}$ & $\begin{array}{l}30.39116 \\
(14.9058)\end{array}$ & $\begin{array}{l}3.169520 \\
(5.72182)\end{array}$ \\
\hline 6 & 0.047540 & $\begin{array}{l}69.32351 \\
(15.0545)\end{array}$ & $\begin{array}{l}27.17855 \\
(14.9304)\end{array}$ & $\begin{array}{l}3.497941 \\
(5.97923)\end{array}$ \\
\hline 7 & 0.051426 & $\begin{array}{l}71.88838 \\
(15.2068)\end{array}$ & $\begin{array}{l}24.59577 \\
(15.1070)\end{array}$ & $\begin{array}{l}3.515857 \\
(6.00656)\end{array}$ \\
\hline 8 & 0.054619 & $\begin{array}{l}73.53076 \\
(15.5322)\end{array}$ & $\begin{array}{l}22.96874 \\
(15.3705)\end{array}$ & $\begin{array}{l}3.500501 \\
(6.18420)\end{array}$ \\
\hline 9 & 0.057425 & $\begin{array}{l}74.86847 \\
(16.0113)\end{array}$ & $\begin{array}{l}21.69490 \\
(15.7323)\end{array}$ & $\begin{array}{l}3.436638 \\
(6.52594)\end{array}$ \\
\hline 10 & 0.060194 & $\begin{array}{l}75.90494 \\
(16.3617)\end{array}$ & $\begin{array}{l}20.46750 \\
(15.9069)\end{array}$ & $\begin{array}{l}3.627568 \\
(6.99825)\end{array}$ \\
\hline $\begin{array}{l}\text { Variance } \\
\text { Period }\end{array}$ & $\begin{array}{l}\text { e Decompositio } \\
\text { S.E. }\end{array}$ & $\begin{array}{l}\text { of } \operatorname{Ln}\left(\mathrm{CO}_{2} \mathrm{PC}\right) \text { : } \\
\operatorname{Ln}(\mathrm{GDPPC})\end{array}$ & Ln(PECPC) & $\mathrm{Ln}\left(\mathrm{CO}_{2} \mathrm{PC}\right)$ \\
\hline 1 & 0.027759 & $\begin{array}{l}41.98710 \\
(12.6648)\end{array}$ & $\begin{array}{l}17.06186 \\
(8.95856)\end{array}$ & $\begin{array}{l}40.95105 \\
(10.5541)\end{array}$ \\
\hline 2 & 0.034487 & $\begin{array}{l}51.20359 \\
(13.3895)\end{array}$ & $\begin{array}{l}18.03576 \\
(10.6868)\end{array}$ & $\begin{array}{l}30.76065 \\
(9.81915)\end{array}$ \\
\hline 3 & 0.045855 & $\begin{array}{l}61.35616 \\
(13.9521)\end{array}$ & $\begin{array}{l}20.49883 \\
(12.5345)\end{array}$ & $\begin{array}{l}18.14501 \\
(7.71161)\end{array}$ \\
\hline 4 & 0.052149 & $\begin{array}{l}62.80768 \\
(15.2293)\end{array}$ & $\begin{array}{l}21.53394 \\
(14.6495)\end{array}$ & $\begin{array}{l}15.65838 \\
(8.02096)\end{array}$ \\
\hline 5 & 0.055290 & $\begin{array}{l}64.02330 \\
(16.1040)\end{array}$ & $\begin{array}{l}21.17449 \\
(15.7731)\end{array}$ & $\begin{array}{c}14.80221 \\
(8.51577)\end{array}$ \\
\hline 6 & 0.059547 & $\begin{array}{l}64.38948 \\
(16.3198)\end{array}$ & $\begin{array}{l}19.83201 \\
(16.1753)\end{array}$ & $\begin{array}{l}15.77851 \\
(9.06162)\end{array}$ \\
\hline 7 & 0.062906 & $\begin{array}{l}64.33839 \\
(16.7348)\end{array}$ & $\begin{array}{l}19.11261 \\
(16.5867)\end{array}$ & $\begin{array}{l}16.54899 \\
(9.63411)\end{array}$ \\
\hline 8 & 0.066624 & $\begin{array}{l}65.01806 \\
(17.2137)\end{array}$ & $\begin{array}{l}18.90046 \\
(16.9487)\end{array}$ & $\begin{array}{l}16.08147 \\
(9.79449)\end{array}$ \\
\hline 9 & 0.070384 & $\begin{array}{l}65.01228 \\
(17.7949)\end{array}$ & $\begin{array}{l}19.20115 \\
(17.4856)\end{array}$ & $\begin{array}{c}15.78657 \\
(10.1461)\end{array}$ \\
\hline 10 & 0.073185 & $\begin{array}{l}64.94026 \\
(18.3922)\end{array}$ & $\begin{array}{l}19.50984 \\
(17.9597)\end{array}$ & $\begin{array}{l}15.54990 \\
(10.6118)\end{array}$ \\
\hline
\end{tabular}

